\title{
Foraminiferal and palynological records of the Late Badenian (Middle Miocene) transgression in Podolia (Shchyrets near Lviv, western Ukraine)
}

\author{
Danuta PERYT ${ }^{1, *}$, Przemysław GEDL ${ }^{2}$ and Tadeusz Marek PERYT ${ }^{3}$ \\ 1 Polish Academy of Sciences, Institute of Paleobiology, Twarda 51/55, 00-818 Warszawa, Poland \\ 2 Polish Academy of Sciences, Institute of Geological Sciences, Senacka 1, 31-002 Kraków, Poland \\ 3 Polish Geological Institute - National Research Institute, Rakowiecka 4, 00-975 Warszawa, Poland
}

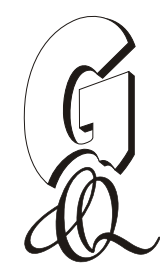

Peryt, D., Gedl, P., Peryt, T.M., 2014. Foraminiferal and palynological records of the Late Badenian (Middle Miocene) transgression in Podolia (Shchyrets near Lviv, western Ukraine). Geological Quarterly, 58 (3): 465-484, doi: 10.7306/gq.1195

\begin{abstract}
The Upper Badenian marly shales overlying gypsum and the Ratyn Limestone at Shchyrets, Ukraine, contain moderately to well-preserved benthic (calcareous only) and planktonic foraminifers, and palynofacies dominated by bisaccate pollen grains, presumably transported by wind. Both foraminiferal and dinoflagellate cyst assemblages indicate an open marine environment with normal-marine salinity and cool waters. The palaeodepth was ca. $50 \mathrm{~m}$ except for the uppermost part of the section studied, where a distinctive deepening is indicated by the dominance of Uvigerina in benthic foraminiferal assemblages and a high P/B ratio. The water was thermally stratified and the differences between the bottom water and the water column show an upwards-increasing trend. Bulimina and Globocassidulina are the most common and dominant component of benthic foraminiferal assemblages, except for the uppermost part where Uvigerina dominates the assemblage. The composition of benthic foraminifer assemblages and $\delta^{13} \mathrm{C}$ values of foraminifers indicate nutrient-rich waters and mesotrophic to eutrotrophic environments in surface waters, and low oxygenation at the sea floor in the Ukrainian Carpathian Foredeep Basin during the Late Badenian.
\end{abstract}

Key words: Paratethys, Carpathian Foredeep, Upper Badenian, foraminifers, dinoflagellate cysts, palaeoenvironment.

\section{INTRODUCTION}

Following the mid-Badenian salinity crisis, which resulted in the deposition of thick evaporite deposits in various basins of the Carpathian region (see Peryt, 2006 with references therein), the last marine flooding in the Paratethys in the Late Badenian resulted in the reconnection of the Central and Eastern Paratethys (Rögl, 1998). During this transgression, which was dominantly controlled by sea level changes outside the Central Paratethys realm (Kováč et al., 2007), outer and inner neritic conditions were established in the inner and outer parts of the foredeep, and in the marginal part of the Carpathians (Oszczypko and Oszczypko-Clowes, 2012 with references therein). There are various estimates of the transgression start: from ca. 13.1 Ma (Śliwiński et al., 2012) to ca. 13.54 Ma (Hohenegger et al., 2014). De Leeuw et al. (2013) suggested that the end of the Badenian salinity crisis was at 13.36 Ma.

The Upper Badenian deposits show carbonate facies characterized by the occurrence of coralline algae-vermetid reefs and a variety of bioclastic facies in the eastern part of the

\footnotetext{
* Corresponding author: d.peryt@twarda.pan.pl
}

Received: August 13, 2014; accepted: September 24, 2014; first published online: October 7, 2014
Carpathian foreland (Kudrin, 1966; Górka et al., 2012), and then, towards the west, by rhodoid limestones with minor intercalations of marl and claystone (Gedl and Peryt, 2011; Studencka et al., 2012); farther towards the south-west this carbonate facies is replaced by clayey-sandy-carbonate facies that, in turn, passes into sandy-clayey facies - the typical Kosiv Suite. The sedimentary facies changes are accompanied by changes in foraminiferal assemblages, and the most basinward, clayey facies contain chilostomellids, cassidulinids, buliminids, and some planktonic species (Orbulina, Globigerina) (Bobrinskaya et al., 1998).

The Kosiv Formation consists of silty grey clays which alternate with separate interbeds of loose silts, sandstones, tuffs, and tuffites (Andreyeva-Grigorovich et al., 1997). It is composed of four lithologically distinctive subdivisions: the Verbovets, Prut, Kolomyia, and Kovalivka beds.

The Verbovets beds contain several layers of tuff and tuffite, and are characterized by numerous Globigerina bulloides d'Orbigny, G. regularis d'Orbigny, Subbotina cognata (Pishvanova), and Velapertina indigena (Łuczkowska). In addition, radiolarians occur in the lower part of the subdivision, while pteropods of the genus Spiratella, and foraminifera, occur in its upper part (Pishvanova, 1969; Garecka and Olszewska, 2011). Foraminiferal assemblages were assigned to the Globigerina decoraperta Zone. Within the Prut beds, sandstones predominate (Andreyeva-Grigorovich et al., 1997). The Prut beds are characterized by the co-occurrence of agglutinated and calcareous foraminifera of the Bogdanowiczia pokutica and Bulimina- 
-Bolivina zones, with typical Hyperammina granulosa Venglinski, Bogdaniowiczia pokutica Pishvanova, Cyclammina pleschakovi Pishvanova, and numerous Bulimina elongata d'Orbigny (Pishvanova, 1969; Garecka and Olszewska, 2011).

The aim of this paper is to characterize and interpret the environmental changes from the succession of foraminiferal assemblages, palynofacies, and assemblages of dinoflagellate cysts in the basal part of the Kosiv Formation at Shchyrets, near Lviv, that is one of key sections of the Upper Badenian in the Ukrainian Carpathian Foredeep, owing to its palaeogeographical location near the boundary of marginal and basinal parts of the foredeep (Fig. 1).

\section{GEOLOGICAL SETTING}

Shchyrets is located north of the Rava Ruska Fault Zone that is commonly considered to represent the southwestern edge of the East-European Platform. South of the Rava Ruska Fault Zone, strata of the Bilche-Volytsia zone of the Carpathian Foredeep occur.

The Bilche-Volytsia Unit shows diverse stratigraphic sequences and varied thicknesses of Miocene deposits (Oszczypko et al., 2006). At the base of the Miocene section in borehole profiles of the Bilche-Volytsia Unit, various siliciclastic deposits, commonly conglomerates and breccias, and carbonate deposits occur that are included in the Sandy-Calcareous Series of the Karpatian (Vashchenko et al., 2007) or Early Badenian (Kotarba et al., 2011) age; in the latter case, they form part of the Bohorodchany Formation that is covered by evaporites of Tyras Formation (Peryt et al., 2010). In the Carpathian foreland, the Tyras Formation includes evaporites and the Ratyn Limestone (Petryczenko et al., 1994; Andre-
yeva-Grigorovich et al., 1997). The formation is overlain by the Upper Badenian Kosiv Formation (10-150 m thick); the overlying Sarmatian strata are included in the Dashava Formation that is further subdivided into two parts; the lower part (up to $3500 \mathrm{~m}$ thick), and the upper part (up to $1500 \mathrm{~m}$ thick) (Kurovets et al., 2004).

Various types of the Badenian deposits are exposed naturally in the Shchyrets area (Łomnicki, 1897; cf. Gerasimov et al., 2005). In the gypsum quarry (not active at present), clastic, laminated, and redeposited gypsum of total thickness of ca. $20 \mathrm{~m}$, with ca. $5 \mathrm{~m}$ thick breccia intercalation and nucleation cones at their base (Peryt, 1996), is overlain by the Ratyn Limestone (ca. $0.9 \mathrm{~m}$ thick; Fig. 2). The Ratyn Limestone shows mudstone and then peloidal and intraclastic wackestone-packstone texture (Peryt and Peryt, 1994). Its isotopic composition suggests that both marine facies $\left(\delta^{18} \mathrm{O}\right.$ values from -3 to $+1 \%$; $\delta^{13} \mathrm{C}$ values from ca. $-9 \%$ ) and diagenetic material $\left(\delta^{18} \mathrm{O}\right.$ values from ca. -1 to $-5 \%$; $\delta^{13} \mathrm{C}$ values from ca. -13.5 to $-15.5 \%$ ) occur (Peryt and Peryt, 1994: fig. 3; cf. Peryt et al., 2012).

The Ratyn Limestone is overlain by $5 \mathrm{~m}$ thick pale beige to pale olive hard, massive marly clays, with one $20 \mathrm{~cm}$ thick bed of carbonatized tuffite located 1.5-1.7 m above the Ratyn Limestone, a $15 \mathrm{~cm}$ thick sandstone intercalation occurring $2.9 \mathrm{~m}$ above the Ratyn Limestone, and a $35 \mathrm{~cm}$ thick bed of carbonatized tuffite at the top (Fig. 2). In addition, there occur thinner tufogenic intercalations; one of these, occurring about $2.5 \mathrm{~m}$ above the gypsum, was radiometrically dated to $13.19 \pm$ $0.14 \mathrm{Ma}$ (Nejbert et al., 2012). These marly clays contain foraminifers; Kudrin (1966: p. 140) mentioned that N. Boyarintsevaya found rare Textularia carinata d'Orbigny, Gyroidina soldanii d'Orbigny, Uvigerina pygmea d'Orbigny, Bulimina elongata d'Orbigny, B. buchiana d'Orbigny, Pullenia coryelli White, Globigerina ex gr. bulloides d'Orbigny, and Miliolina sp. in the "tuffaceous sandstones" of Shchyrets.

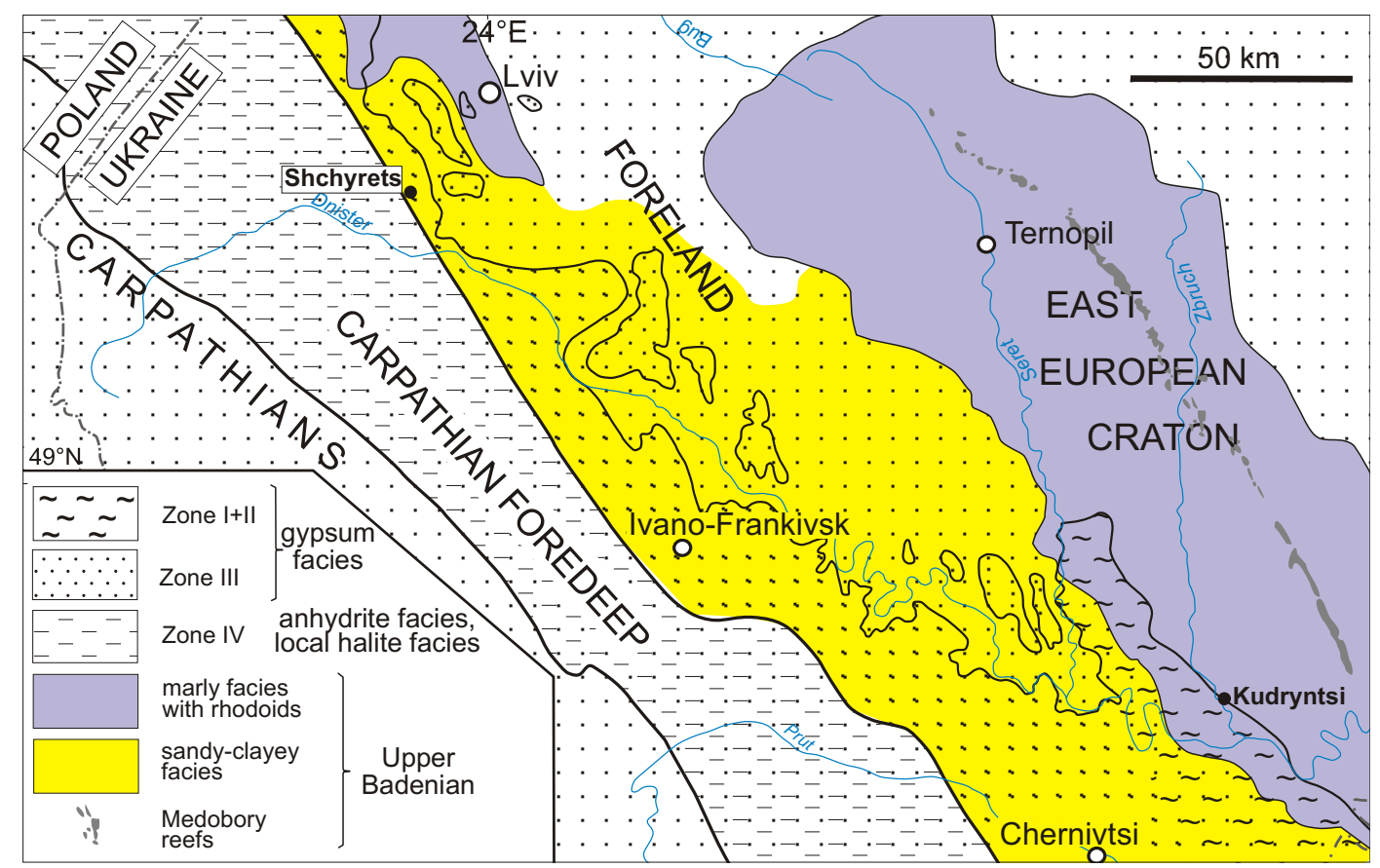

Fig. 1. Location map showing the mid-Badenian sulphate zones (after Peryt, 2006) and Upper Badenian facies in the Carpathian foreland (after Kudrin, 1966) 


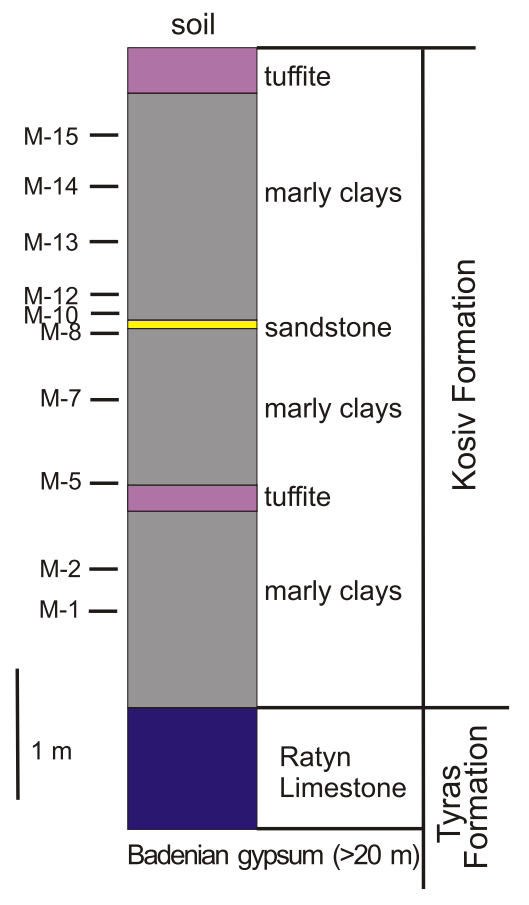

Fig. 2. Upper Badenian section at Shchyrets Quarry showing sample locations

\section{MATERIAL AND METHODS}

The section exposed in the Shchyrets Quarry was measured and sampled in 1996. Nine samples were selected for study of foraminifers, palynology and mineralogical composition. The location of samples studied is shown in Figure 2.

Samples M-1 to M-8 are pale beige to pale olive hard, massive marly shales, and samples $\mathrm{M}-10$ to $\mathrm{M}-15$ are mostly pale beige fine-splitting marly shales.

Washed residues for foraminiferal study were obtained from the marls by disaggregation using $\mathrm{Na}_{2} \mathrm{SO}_{4}$. An aliquot of about 200-300 specimens of foraminifers from the 100-600 $\mu \mathrm{m}$ size fraction was picked for the faunal analyses. Taxonomy of the foraminifers follows Loeblich and Tappan (1987), Odrzywolska-Bieńkowa and Olszewska (1996) and Cicha et al. (1998). The figured specimens are deposited in the Institute of Paleobiology, Polish Academy of Sciences, Warszawa (ZPAL F. 60).

Foraminiferal taxa were allocated to morphogroups according to Jones and Charnock (1985) and Corliss and Chen (1988). The relative percentages of benthic foraminifer species within the benthic foraminiferal assemblages, the relative abundance of infaunal, shallow infaunal and epifaunal forms (to inform on trophic conditions), and the percentage of planktonic foraminifers within total foraminiferal assemblages ( $P / B$ ratio) were calculated. Palaeobathymetry was estimated on the basis of benthic faunal characteristics and the P/B ratio. The palaeoenvironmental interpretation, based on foraminifers, applies the requirements of present-day representatives of recorded taxa (see Peryt and Gedl, 2010: table 1). To estimate the level of oxygenation of the sea floor, benthic foraminifera were grouped into oxic, suboxic, and dysoxic indicators according to Thomas (1980), van der Zwaan (1982, 1983), Verhallen (1991), Jorissen et al. (1992), Kaiho (1994), Loubére (1996, 1997), Bernhard and Sen Gupta (1999), Kouwenhoven and van der Zwaan (2006), and Kaminski (2012).
The following taxa, present in the material studied, are included in the oxic group: Heterolepa dutemplei, Lobatula lobatula, Cibicidoides spp., Cibicides sp., Sigmoilinita tenuis. Oxic indices represent epifaunally living species. Taxa tolerant of suboxic environments are: Lenticulina spp., Lagena spp., Porosononion granosum, Astrononion perfossum, Melonis pompilioides, Pullenia bulloides, P. miocenica, Sphaeroidina bulloides, and taxa tolerant of dysoxic environments are Bulimina spp., Bolivina spp., Uvigerina spp., Fursenkoina acuta, Praeglobobulimina pyrula and Globocassidulina sp. Foraminifers tolerant of suboxic environments represent mostly shallow infaunally living species, while foraminifers tolerant of dysoxic environments represent mostly deep infauna and species with opportunistic behavior. They are commonly used as stress markers (e.g., van der Zwaan et al., 1999; van Hinsbergen et al., 2005).

Since Emiliani (1955), $\delta^{18} \mathrm{O}$ values of foraminifera are regarded as an excellent indicator of temperature changes. To calculate absolute water temperature, $\delta^{18} \mathrm{O}$ ratios of selected foraminifer species were used: planktonic Globigerina spp. (in four samples, in two of them G. bulloides) and infaunal Bulimina elongata. In one case where the latter taxon was too rare to allow for isotopic studies, Uvigerina peregrina was used instead, as both have similar environmental requirements, and in another sample both Bulimina elongata and Uvigerina peregrina were used. It is assumed that the isotope values for Globigerina and Bulimina/Uvigerina are indicative of the surface and deep-water isotope composition, respectively. Foraminifer tests were reacted with $100 \%$ phosphoric acid at $75^{\circ} \mathrm{C}$, using a KIEL IV online automatic carbonate preparation line connected to the Finnigan Mat delta plus mass-spectrometer at the Light Stable Isotopes Laboratory of the Institute of Geological Sciences, Polish Academy of Sciences, Warszawa. All isotopic data was reported in per mil relative to VPDB related to NBS 19. The precision (reproducibility of replicate analyses) of both carbon and oxygen isotope analyses was usually better than $\pm 0.2 \%$. For the calculation of palaeotemperatures, various equations have been generated, but all generally follow Epstein et al.'s (1953) original equation. In the present work we use this original equation. Due to various corrections, the final temperature values for Late Badenian Paratethyan water can differ substantially (see Peryt, 2013: appendix 3), although the trends of temperature changes, based on calculations with various equations, remain stable.

The samples were processed following standard palynological procedure, including $38 \%$ hydrochloric acid $(\mathrm{HCl})$ treatment, $40 \%$ hydrofluoric acid $(\mathrm{HF})$ treatment, heavy liquid $\left(\mathrm{ZnCl}_{2}+\mathrm{HCl}\right.$; density $\left.2.0 \mathrm{~g} / \mathrm{cm}^{3}\right)$ separation, ultrasound for $10-15 \mathrm{~s}$, and sieving at $15 \mu \mathrm{m}$ on a nylon mesh. No fuming nitric acid $\left(\mathrm{HNO}_{3}\right)$ treatment was applied. The quantity of rock processed equalled $20 \mathrm{~g}$ for each sample. The rock samples, palynological residues and slides are stored in the collection of the Institute of Geological Sciences, Polish Academy of Sciences, Kraków.

Palynomorphs and phytoclasts were counted up to a total of 1000. Among palynomorphs dinoflagellate cysts, sporomorphs (spores and pollen grains), and Leiosphaeridia were distinguished, whereas palynodebris consist in the material studied of cuticular remains, black opaque phytoclasts, dark brown translucent woody particles and structureless debris. All dinoflagellate cysts on a slide were counted.

Samples were subject to X-ray Diffraction (XRD) study using a Philips X'Pert PW 3020 spectrometer at the Central Chemical Laboratory of the Polish Geological Institute - National Research Institute, Warszawa. The wavelength used was K-Alpha1 and the peak search parameter set was PC-APD. 


\section{RESULTS}

\section{FORAMINIFERS}

The deposits examined yielded moderately- to well-preserved foraminifers (Figs. 3-5). Benthic assemblages are composed entirely of calcareous forms (Figs. 3 and 4); agglutinated foraminifers were not recorded in the material studied. Simple benthic diversity is low to moderate. Thirty-eight species of benthic and nine species of planktonic foraminifers were recorded.

Bulimina is the most common and dominant component of benthic foraminiferal assemblages in almost the entire interval studied, except in the uppermost part, where this group is completely lacking. In places, Uvigerina and Globocassidulina, at the expense of Bulimina, exceed $50 \%$ and dominate assemblages. Fursenkoina, Heterolepa dutemplei, and Sphaeroidina bulloides are also temporarily important contributors, forming up to $25 \%$ of the assemblages; Pullenia bulloides, Sigmoilinita tenuis, Astrononion perfossum are common in different intervals (Fig. 6).

The contribution of planktonic foraminifera is very low $(0-5 \%)$ except in the uppermost part of the section, where the P/B ratio exceeds $50 \%$. Globigerina and Globigerinelloides are the most common; Tenuitellinata, Globigerinoita, Turborotalita, and Velapertina? were also recorded (Fig. 5).

In sample M-1, the benthic foraminiferal assemblage is dominated by Bulimina aculeata and Bulimina elongata; common are Sigmoilinita tenuis and Lagena sp.; Bolivina sp., Sphaeroidina bulloides, Astrononion perfossum, Elphidium macellum, Cibicidoides sp. and Praeglobobulimina sp. rarely occur (Fig. 6). Dysoxic indices form $80 \%$ of the assemblage and are composed mainly of Bulimina spp.; Bolivina and Praeglobobulimina are minor contributors to this group; suboxic indices form $13 \%$ of the assemblage, and oxic ones only 7\% (Fig. 7). Planktonic foraminifera are rare and are represented by Globigerina bulloides, G. praebulloides, Globigerina sp., and Globigerinoides sp. In addition, reworked Cretaceous foraminifera occur.

In sample M-2, Bulimina, a dominant form in the preceding sample, decreases in relative abundance to $38 \%$ of the assemblage (Fig. 6). Small thin-walled Lagena spp., Astrononion perfossum, Reussoolina apiculata, Lobatula lobatula, Cibicidoides sp., Eponides repandus, and Polymorphina? sp. are common. In this assemblage the contribution of dysoxic forms is the lowest in the entire interval studied and reaches 38\%; the suboxic group is the largest and forms $48 \%$ of the total, and oxic forms comprise $14 \%$ (Fig. 7). The planktonic foraminifera assemblage is the same as in sample M-1.

In sample M-5, Bulimina again is the main component of the benthic foraminiferal assemblage (70\% of the total). Bulimina aculeata and $B$. elongata are the most abundant. Heterolepa dutemplei is also a very important contributor and exceeds $25 \%$ of the assemblage. Minor components are Astrononion perfossum, Reussoolina apiculata, Elphidium sp., Melonis pompilioides, Uvigerina sp., and Sphaeroidina bulloides (Fig. 6). Dysoxic indices contribute $65 \%$ of the assemblage; oxic ones represented mainly by Heterolepa dutemplei form $27 \%$, and suboxic forms comprise $8 \%$ (Fig. 7). Planktonic foraminifera are lacking.

In the following sample, M-7, Bulimina exceeds $50 \%$ of the assemblage, Fursenkoina acuta forms 25\%, Astrononion perfossum forms $16 \%$, and Sigmoilinita tenuis makes up $5 \%$ (Fig. 6); in addition rare Heterolepa dutemplei, Bolivina sp., Sphaeroidina bulloides, Elphidium macellum, Cibicidoides sp., Praeglobobulimina pyrula, Guttulina sp. and Glandulina ovula occur. Bulimina and Fursenkoina acuta are main dysoxic forms and their contribution to the assemblage exceeds $75 \%$; suboxic species form $20 \%$ and oxic species form only $5 \%$ (Fig. 7 ). Planktonic foraminifera, represented by small Globigerina spp. and Globigerinoides spp., form $5 \%$ of the assemblage.

In sample M-8, the contribution of Bulimina drops to $30 \%$; Globocassidulina sp. dominates (53\% of the assemblage); Sigmoilinita tenuis and Astrononion perfossum are common in this assemblage; rare components are represented by Lagena sp., Lenticulina sp., Reussoolina apiculata, Porosononion martkobi, Bolivina spp., and Glandulina ovula (Fig. 6). In this assemblage dysoxic forms dominate, reaching $86 \%$; suboxic representatives drop to $10 \%$ and oxic ones form $4 \%$ (Fig. 7 ). Planktonic foraminifera are rare and do not exceed $5 \%$ of the assemblage.

In sample M-10 Bulimina dominates (B. aculeata and Bulimina elongata are the most abundant); Astrononion perfossum and Sigmoilinita tenuis exceed 13 and $10 \%$, respectively (Fig. 6). In this assemblage, the contribution of dysoxic forms is $68 \%$, and of suboxic ones is $20 \%$; oxic indices form $12 \%$ (Fig. 7). Planktonic forms are represented by Globigerinoides spp., Globigerina bulloides, G. praebulloides, and Globigerina sp.; their contribution to the assemblage is $<5 \%$.

In sample $\mathrm{M}-12$, the taxonomic composition of benthic foraminiferal assemblage is very similar to that of sample $\mathrm{M}-8$, where Bulimina is common but not dominant (Fig. 6). Globocassidulina sp. dominates in this assemblage. Minor components are Sphaeroidina bulloides, Lagena sp., Pullenia bulloides, Lenticulina sp., Reussoolina apiculata, Porosononion martkobi and Glandulina ovula. Dysoxic species dominate and form $87 \%$ of the assemblage, suboxic species comprise $6 \%$, and oxic forms make up 7\% (Fig. 7). Planktonic foraminifera are very rare and represented by Globigerina spp.

In sample M-13, Bulimina spp. dominate and form $63 \%$ of the assemblage; Sigmoilinita tenuis is common and represents $10 \%$; rare components in this assemblage are represented by Astrononion perfossum, Lagena sp., Lenticulina sp., Reussoolina apiculata, Porosononion martkobi and Glandulina ovula (Fig. 6). Dysoxic representatives form $63 \%$ of the assemblage, suboxic ones $29 \%$, and oxic ones $8 \%$ (Fig. 7 ). Planktonic foraminifera do not exceed $5 \%$ of the assemblage.

The benthic foraminiferal assemblage of sample $\mathrm{M}-14$ is similar in taxonomic composition to that of sample M-12 and is dominated by Globocassidulina sp. $-38 \%$ of the assemblage. Bulimina aculeata and Bulimina elongata are common and together contribute $24 \%$ to the assemblage; common contributors to the assemblage are Sigmoilinita tenuis (9\%) and Astrononion perfossum (6\%); rare components are represented by Glandulina ovula, Lagena sp., Lenticulina sp., Reussoolina apiculata, and Pseudotriloculina consobrina (Fig. 6 ). In the assemblage dysoxic forms dominate $-71 \%$, suboxic ones form $20 \%$, and oxic ones $9 \%$ (Fig. 7). Planktonic forms Globigerina bulloides, G. praebulloides, Globigerina sp., and Globigerinoides spp. - constitute $<5 \%$ of the assemblage.

It is notable that foraminiferal assemblages dominated by Globocassidulina (samples M-8, M-12, and M-14) are characterized by reduced test sizes.

In sample $\mathrm{M}-15$, the benthic foraminiferal assemblage is characterized by the total absence of Bulimina; Uvigerina dominates this assemblage. Uvigerina pudica, $U$. brunnensis, $U$. semiornata, U. peregrina, and Uvigerina sp. form almost $57 \%$ of the total assemblage. An important contributor to this assemblage is Sphaeroidina bulloides, which forms $25 \%$ of the total; common species are Sigmoilinita tenuis (5\%), Bolivina spp. (B. dilatata, B. plicatella and B. sp.) (5\%), Pullenia bulloides (5\%); rare contributors are Globulina punctata, Melonis pompilioides, Cibicidoides sp. and Osangularia? sp. (Fig. 6). Dysoxic compo- 


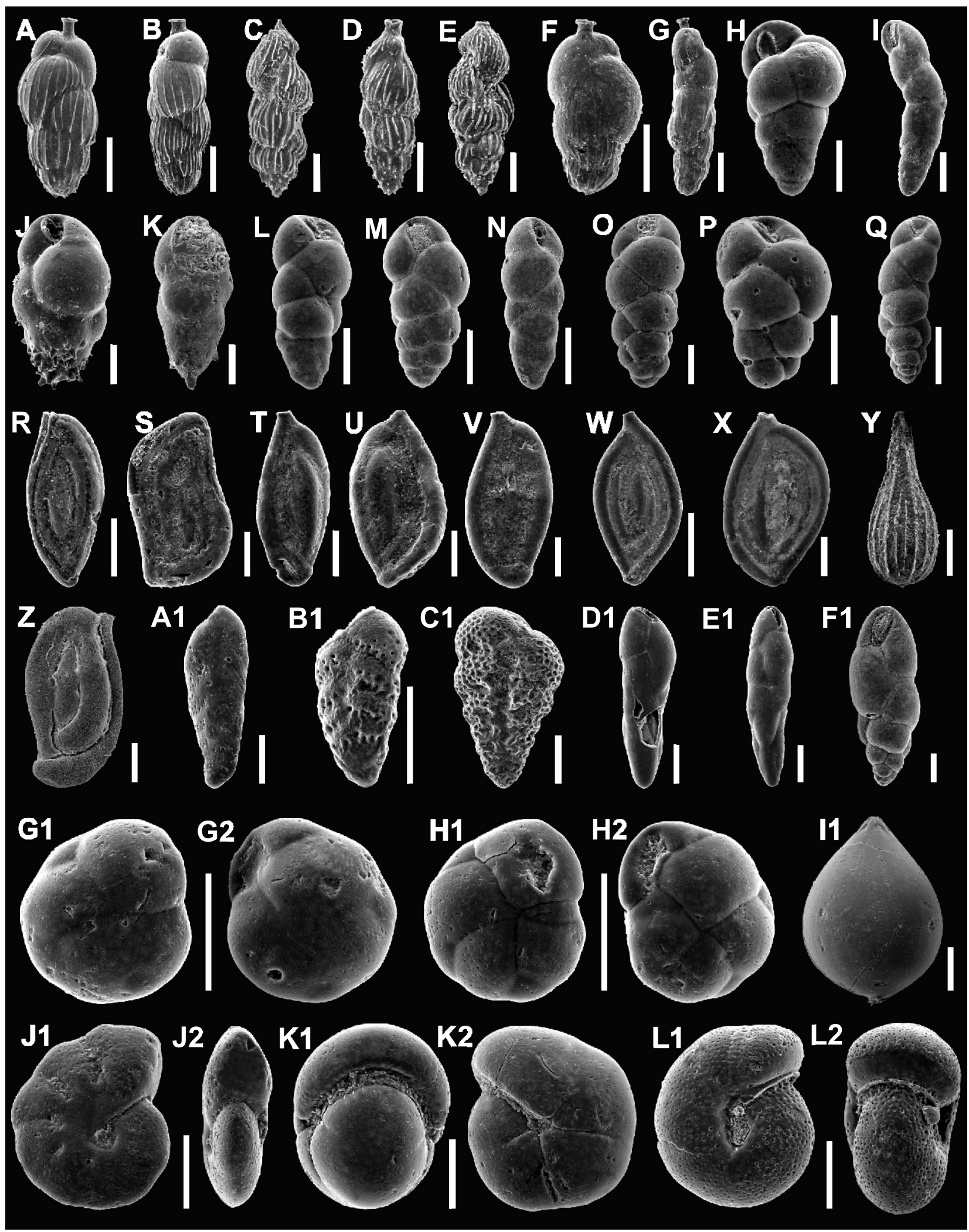

Fig. 3. Benthic foraminifers from Shchyrets

A, B - Uvigerina semiornata; C, D, E - Uvigerina peregrina; F - Uvigerina sp.; G - Uvigerina brunnensis; H - Bulimina sp.; I, N, Q Bulimina elongata; J - Bulimina aculeata; K - Bulimina insignis; L, O, P - Bulimina schischkinskayae; R, S, U, V, W, X - Sigmoilinita tenuis; T - Sigmoilinita sp.; Z - Sigmoilinita tschokrakensis; Y - Lagena sp.; A1 - Bolivina dilatata; B1 - Bolivina sp.; C1 - Bolivina plicatella; D1, E1 - Fursenkoina acuta; F1 - Bolivina sp.; G1, G2, H1, H2 - Globocassidulina sp.; I1 - Glandulina sp.; J1, J2 Astrononion perfossum; K1, K2 - Pullenia bulloides; L1, L2 - Melonis pompilioides; scale bars = $100 \mu \mathrm{m}$ 


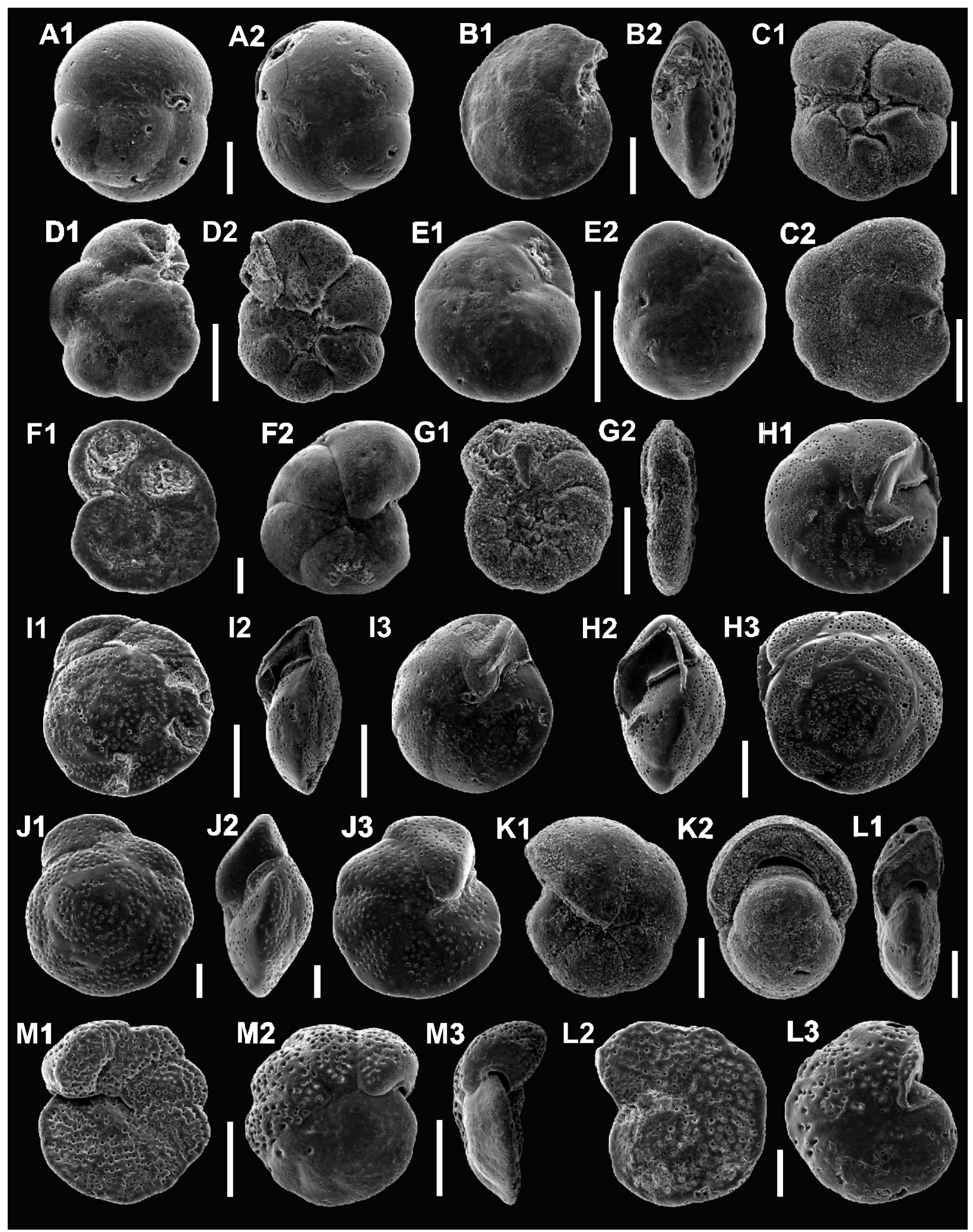

Fig. 4. Benthic foraminifers from Shchyrets

A1, A2 - Sphaeroidina bulloides; B1, B2 - Cibicidoides sp.; C1, C2, D1, D2 - Rosalina nana; E1, E2 - Globocassidulina sp.; F1, F2, L1-L3, M1-M3 - Lobatula lobatula; G1, G2 - Porosononion martkobi; H1-H3, J1-J3 - Heterolepa dutemplei; K1, K2 - Pullenia miocenica; A1, A2, B1, B2, K1, K2 - sample M-15; C1, C2 - sample M-13; D1, D2, E1, E2 - sample M-8; F1, F2, G1, G2, L1-L3, M1-M3 - sample M-2; H1-H3 - sample M-7; I1, I3 - sample M-4; J1-J3 - sample M-5; scale bars = $100 \mu \mathrm{m}$ 


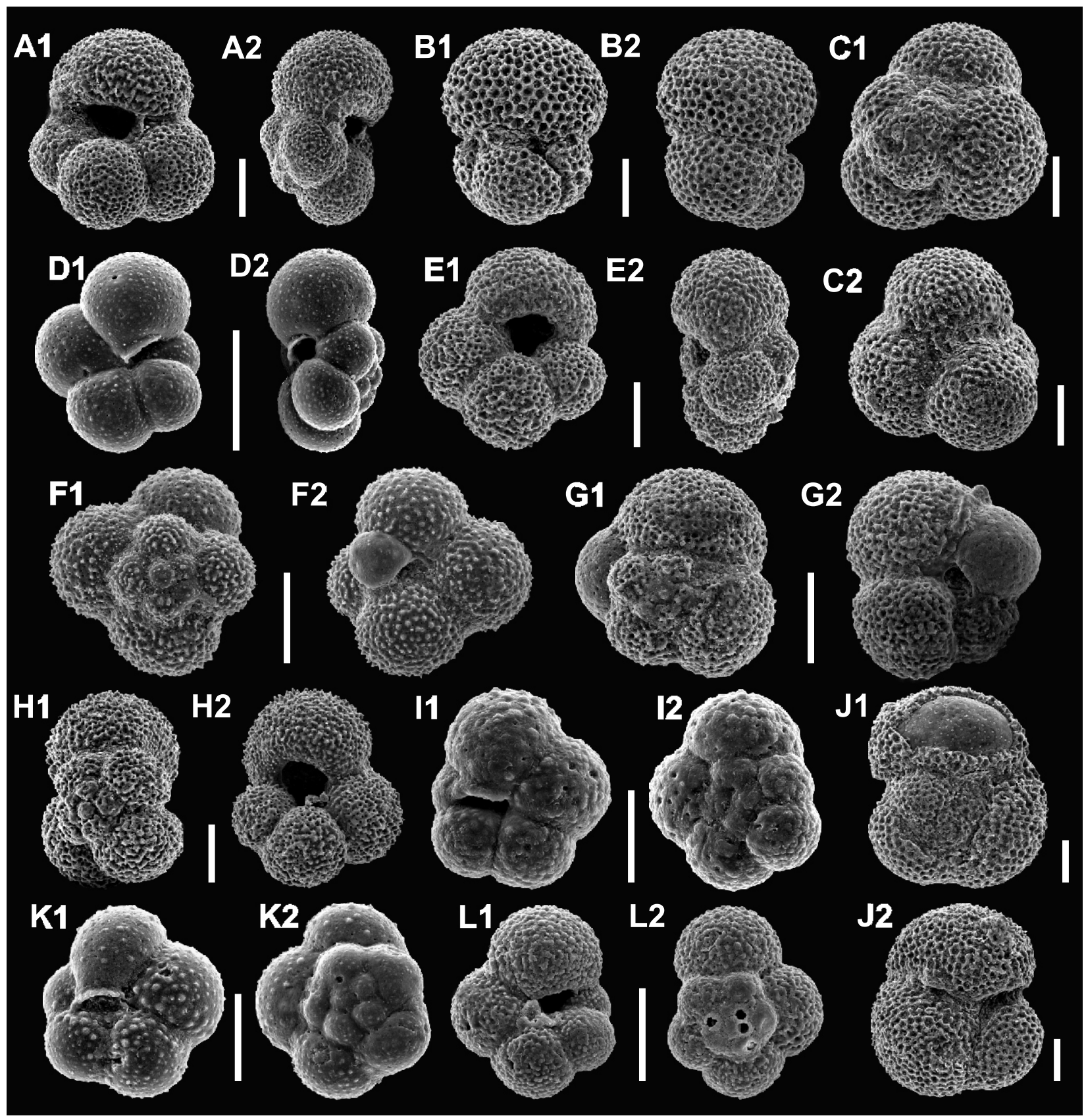

Fig. 5. Planktonic foraminifers from Shchyrets

A1, A2, E1, E2 - Globigerina bulloides; B1, B2 - Globigerinelloides trilobus; C1, C2 - Globigerinoides primordius?; D1, D2, L1, L2 Tenuitellinata juvenilis; F1, F2 - Globigerinoita sp.; G1, G2 - Velapertina? sp.; H1, H2 - Globigerina praebulloides; I1, I2, K1, K2 Turborotalita quinqueloba; J1, J2 - Globigerinoides quadrilobatus; A1, A2, B1, B2, C1, C2, E1, E2, F1, F2, G1, G2, H1, H2, J1, J2, L1, L2 - sample M-15; D1, D2 - sample M-7; I1, I2, K1, K2 - sample M-8; scale bars $=100 \mu \mathrm{m}$

nents form $62 \%$ of the assemblage, suboxic forms $31 \%$ and oxic forms $7 \%$ (Fig. 7 ). $\mathrm{P} / \mathrm{B}$ is $57 \%$. Very common are Globigerinoides spp., Globigerina bulloides, G. praebulloides, and Globigerina sp. Rare occurrences of Tenuitella, Globigerinoita, Turborotalita, and Velapertina are recorded.

\section{ISOTOPIC ANALYSES OF FORAMINIFERS}

Results of isotopic analyses of foraminifers are shown in Figures 8 and 9. The range of $\delta^{13} \mathrm{C}$ values for Bulimina and Uvigerina is from -0.21 to $-2.72 \%$ o (the mean is $-1.13 \pm$ $0.80 \%$ ), and for Globigerina is from -0.41 to $1.72 \%$ o (the mean is $-1.18 \pm 0.62 \%$ ); they are similar. The range of $\delta^{18} \mathrm{O}$ values for Bulimina and Uvigerina is from -0.39 to $2.54 \%$ (the mean is $1.72 \pm 0.99 \%$ ), and for Globigerina from -0.07 to $0.59 \%$ o (the mean is $0.18 \pm 0.29 \%$ ) (Fig. 8).

The benthic $\delta^{13} \mathrm{C}$ curve shows some fluctuation with the lowest values recorded in the bottom part of the section studied. Higher up in the section the $\delta^{13} \mathrm{C}$ values of benthic foraminifers gradually increase up to ca. $0 \%$ near $+2.5 \mathrm{~m}$, then decrease to ca. $-2 \%$ near $+4.0 \mathrm{~m}$ and next, in the uppermost part of the section studied, show an increase to ca. $-0.5 \%$. The benthic $\delta^{18} \mathrm{O}$ curve shows first an increase of $\delta^{18} \mathrm{O}$ values (from $0.94 \%$ to $1.73 \%$ ) and then a distinct decrease (to $-0.39 \%$ just above the thick tuffite bed). Next, in the middle part of the section they in- 


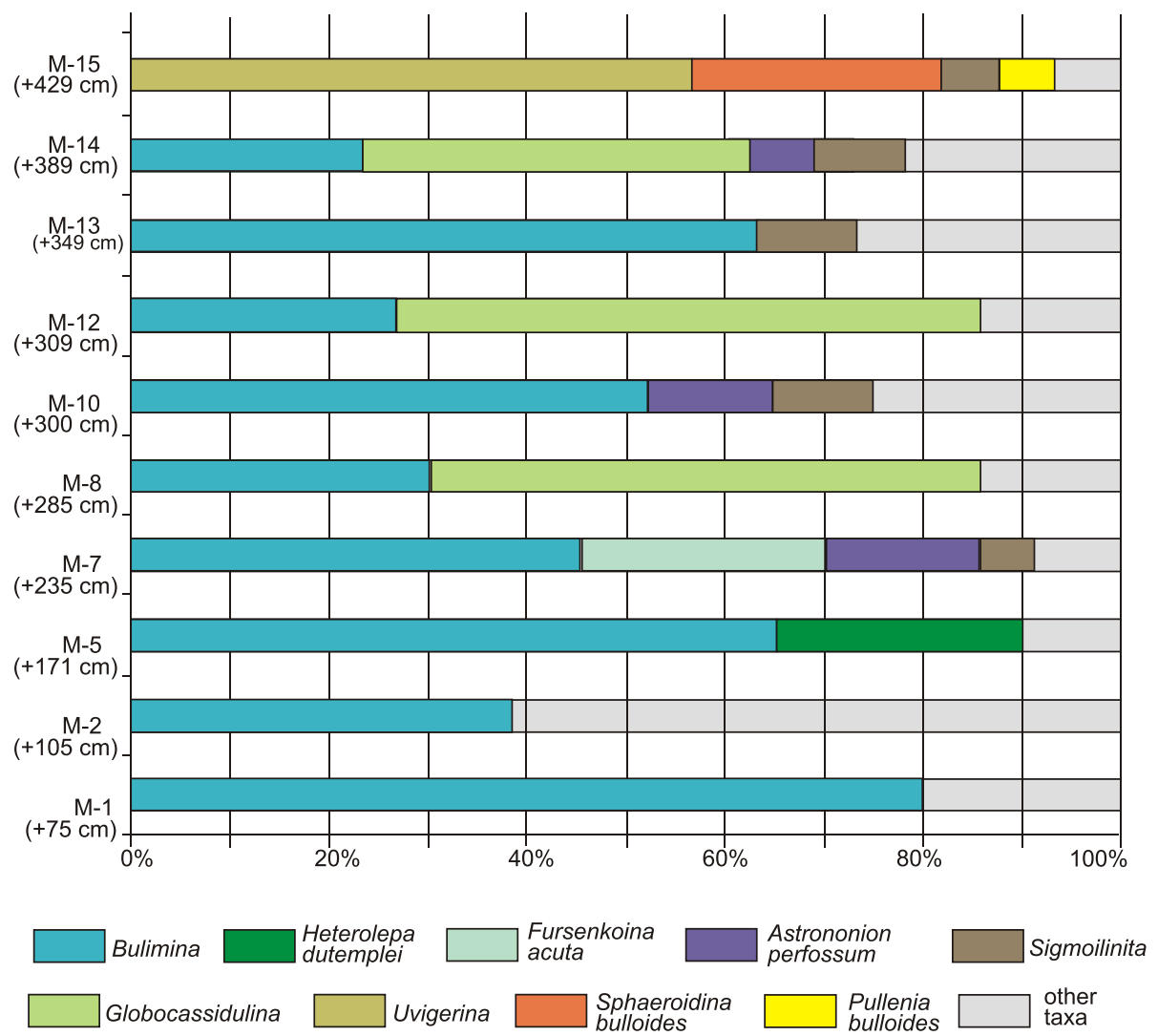

Fig. 6. Relative abundances of dominant and common benthic foraminiferal species within assemblages in the marls above the Ratyn Limestone at Shchyrets

Species or groups of species which at least in one sample exceed $5 \%$ are shown

crease to $2.28 \%$ and the upper part of the sections shows fluctuations in a small range (2.05-2.54\%o). As far as the planktonic foraminifers are concerned, the number of samples analysed was too low to detect the direction of changes in carbon and oxygen isotopes, but limited data indicate the highest $\delta^{13} \mathrm{C}$ values and the lowest $\delta^{18} \mathrm{O}$ values at the base and top of the section, and much a smaller range of fluctuation of $\delta^{18} \mathrm{O}$ values than of $\delta^{13} \mathrm{C}$ values (Fig. 8). There is a distinctive, gradual upwards increase in $\Delta \delta^{18} \mathrm{O}$, from $0.9 \%$ in the lowest sample, to $2.2 \%$ in the highest sample, however, this trend is based on only four samples (Fig. 8).

When compared to roughly coeval foraminifers from other Upper Badenian basins of the Central Paratethys, our data for Globigerina bulloides is similar to data from the Vienna Basin (Fig. 9). As far as our data for benthic foraminifera, mostly Bulimina elongata, is concerned, five of eight samples studied gave results identical or close to those characteristic of Uvigerina of the Vienna Basin, but three samples show deviations in $\delta$ values that are smaller by $1-2 \%$ compared to the $\mathrm{Vi-}$ enna Basin (Fig. 9). Both the Shchyrets section and sections from the Vienna Basin show clearly higher $\delta^{18} \mathrm{O}$ values and clearly lower $\delta^{13} \mathrm{C}$ values that the Upper Badenian Uvigerina and planktonic foraminifera from the Pannonian Basin (Fig. 9).

\section{PALYNOLOGY}

All samples yielded palynological organic matter (Fig. 10). However, its quantity and quality differs in particular samples.
All samples, except for $\mathrm{M}-10$, yielded dinoflagellate cysts; they are illustrated in Figures 11 and 12, and their distribution is shown in Table 1 and Figure 13.

Palynofacies of the lowermost sample M-1 is dominated by sporomorphs (mostly bisaccate pollen grains) - up to $70 \%$; black opaque, dark brown phytoclasts and small-sized cuticles are subordinate - up to $15 \%$; the ratio of highly disintegrated structureless particles is difficult to evaluate, it presumably does not exceed $10 \%$. Aquatic palynomorphs are relatively rare: dinoflagellate cysts are 1-2\%, infrequent Leiosphaeridia occur.

Dinoflagellate cysts are well-preserved; their assemblage is dominated by Spiniferites spp. (over $70 \%$ of all cysts; mainly Spiniferites ramosus). The remaining part of the assemblage consists of common Operculodinium spp., Lingulodinium machaerophorum, Melitasphaeridium pseudorecurvatum, $M$. choanophorum, Labyrinthodinium truncatum, less frequent Systematophora placacantha, Hystrichokolpoma rigaudiae, Nematosphaeropsis labyrinthus, and single specimens of Impagidinium sp. and Systematophora cf. placacantha (Table 1). Rare reworked specimens of reworked Paleogene Cordosphaeridium? funiculatum, and Wetzeliella sp. have been found.

Sample M-2 contains similar palynofacies (Table 1). Dinoflagellate cysts $(2 \%)$ are also dominated by Spiniferites spp., although not so pronouncedly as in lower sample M-1 $40 \%$. Operculodinium spp. and Lingulodinium machaerophorum are very frequent, whereas Melitasphaeridium pseudorecurvatum, $M$. choanophorum, Nematosphaeropsis labyrinthus, Labyrinthodinium truncatum, Reticulatosphaera actinocoronata, and Homotryblium floripes are less common (the lat- 


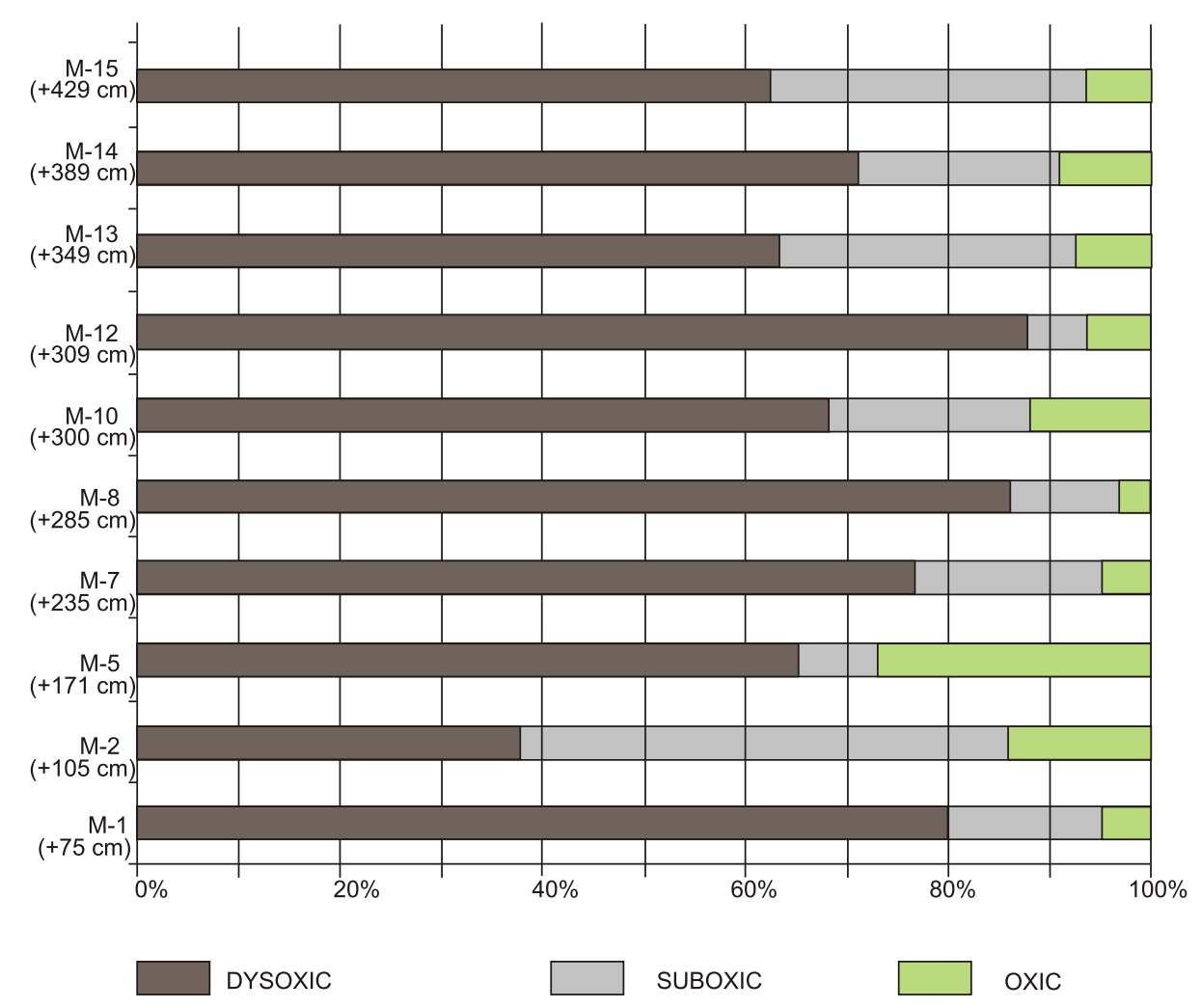

Fig. 7. Relative abundances of dysoxic, suboxic and oxic benthic foraminifers in the Shchyrets section
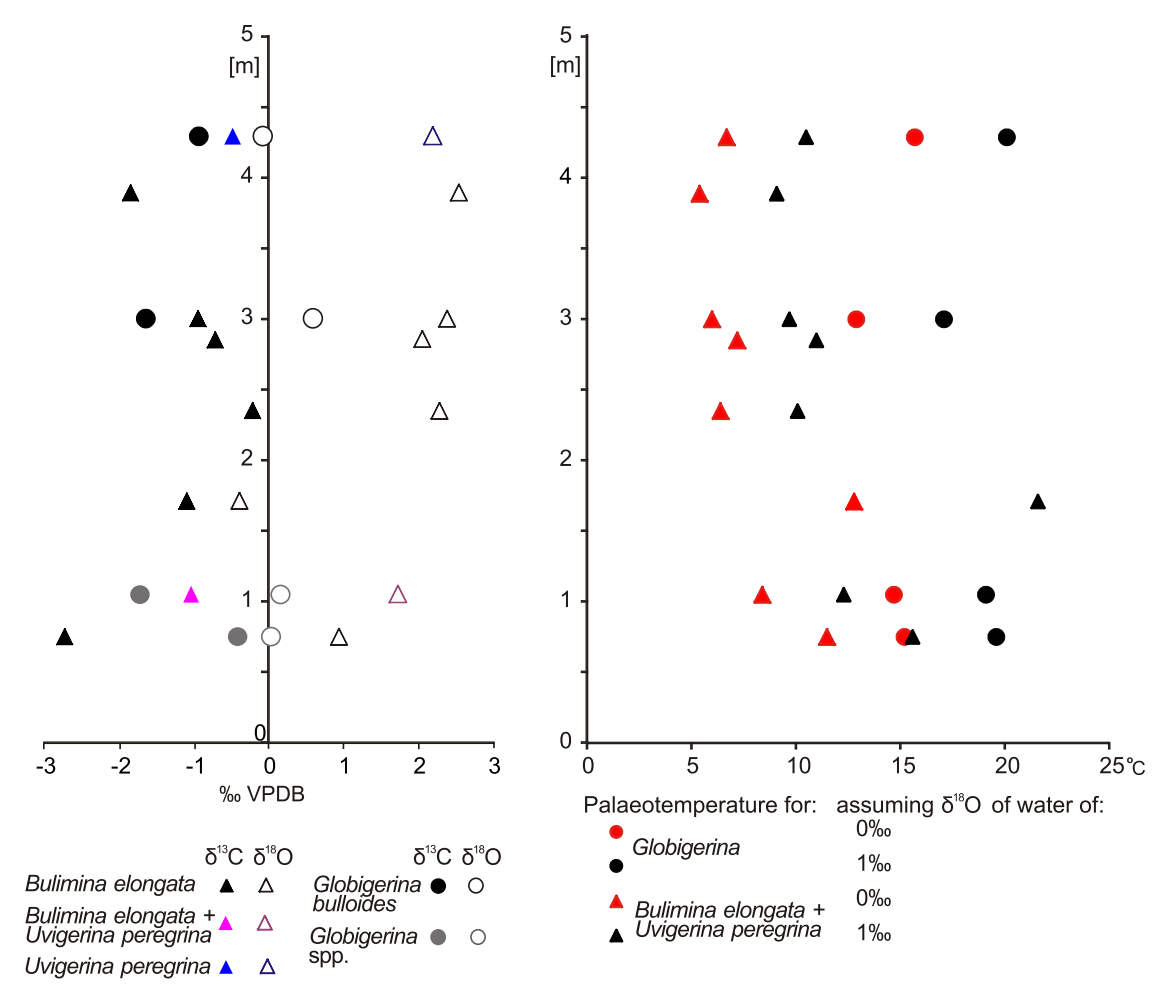

Fig. 8. Isotope profile of foraminifers from Shchyrets Quarry and their palaeotemperatures 


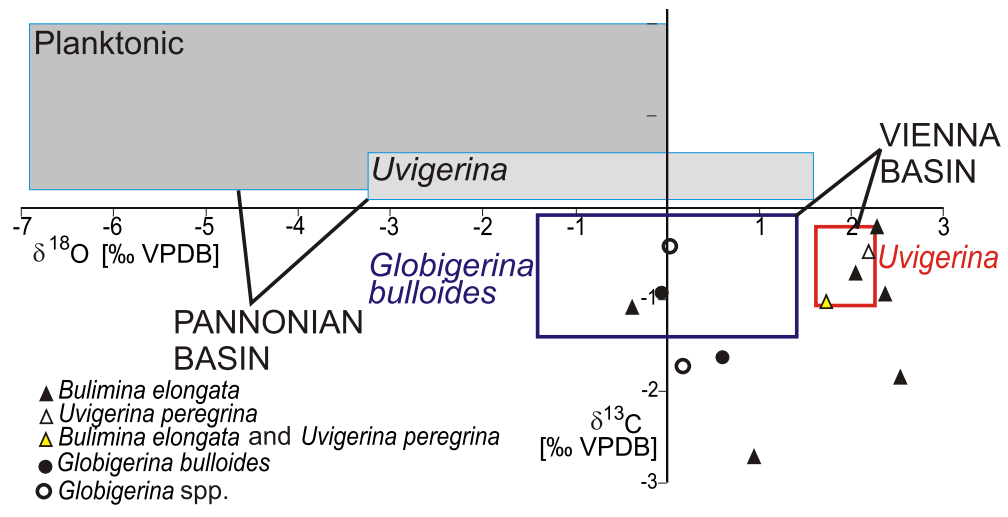

Fig. 9. Plot of $\delta^{13} \mathrm{C}$ and $\delta^{18} \mathrm{O}$ values of Upper Badenian foraminifers from Shchyrets Quarry

ter species might be reworked from Paleogene strata; see Gedl, 2005 for discussion). A single specimen of reworked Cerodinium (Upper Cretaceous-Paleocene) has been found.

The higher sample M-5 is distinguished by a higher ratio of dinoflagellate cysts - up to $15 \%$ (pale-coloured and thin-walled pollen grains form $60 \%$, and highly disintegrated black phytoclasts comprise $25 \%$ ) (Fig. 13). Dinoflagellate cyst assemblage is taxonomically impoverished: it consists of Spiniferites spp., and less frequent Systematophora placacantha, Lingulodinium machaerophorum, and Operculodinium spp. Single specimens of Hystrichokolpoma rigaudiae and Impagidinium cf. aculeatum occur. A single isolated process most likely represents part of a reworked Paleogene specimen of Adnatosphaeridium.

A similar palynofacies occurs in sample M-7: dominating pollen grains (over $70 \%$ ), black and dark brown woody particles $(10 \%)$, small cuticles $(8 \%)$, and aquatic palynomorphs (10\%) (Fig. 13). The latter are represented mainly by dinoflagellate cysts, which are more taxonomically diverse than in the lower sample. Although dominated by Spiniferites spp. (70\%), they also include frequent Operculodinium spp. and Batiacasphaera sp. Moreover, relatively frequent specimens of Nematosphaeriopsis labyrinthus, Labyrinthodinium truncatum, Systematophora placacantha, and Melitasphaeridium choanophorum occur. Rare specimens of Hystrichokolpoma salacia, Dapsilidinium sp., Imperfectodinium septatum, Impagidinium cf. aculeatum, Phelodinium sp., and Reticulatosphaera actinocoronata have been found. A few isolated processes have been found, which, as in sample M5, presumably represent fragments of reworked Paleogene specimens. Aquatic palynomorphs in this sample are also represented by the acritarch Nannobarbophora.

The following two samples, M-8 $(+285 \mathrm{~cm})$ and $\mathrm{M}-10$ $(+300 \mathrm{~cm})$, are characterized by very small amounts of palynological organic matter, which consists almost exclusively of black opaque phytoclasts. Rare bisaccate pollen grains occur in both samples; sample M-8 additionally contains rare dark brown cuticle fragments, and single specimens of Spiniferites
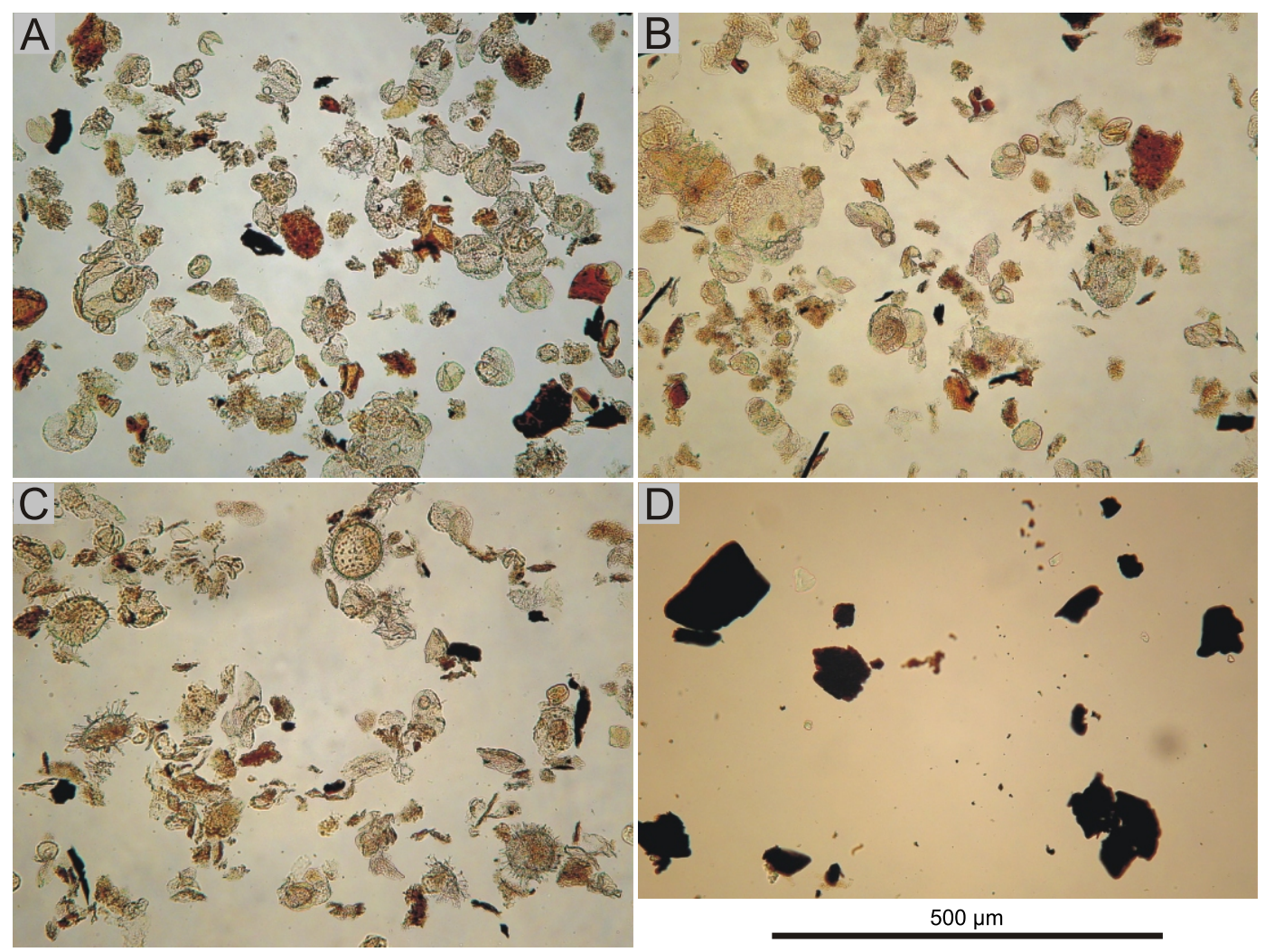

Fig. 10. Palynofacies of the Shchyrets succession

A, B - palynofacies of sample M-1 characterized by domination of pollen grains; dinoflagellate cysts are infrequent; C - sample M-7 showing palynofacies dominated by pollen grains, but aquatic elements (mainly dinoflagellate cysts) show relatively high ratios; $\mathbf{D}$ - palynofacies of sample M-8 consisting almost exclusively of black opaque phytoclasts 
Distribution of dinoflagellate cysts in the Shchyrets succession

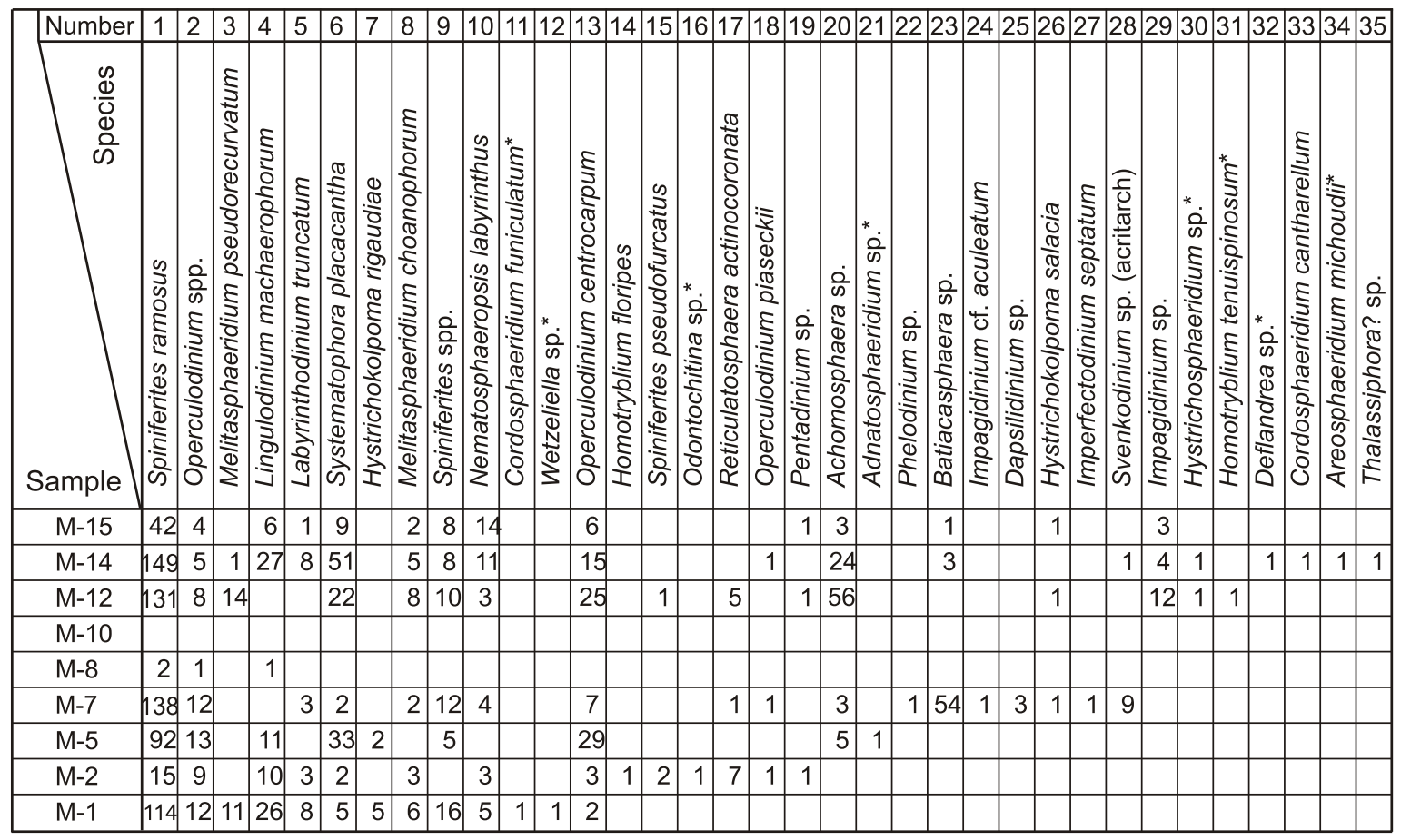

Pre-Miocene reworked species highlighted with an asterisk

sp., Lingulodinium machaerophorum, and Operculodinium centrocarpum (cf. Fig. 13)

The amount of palynological organic matter increases in sample $\mathrm{M}-12$, collected $9 \mathrm{~cm}$ above sample M-10. Its palynofacies consists of sporomorphs $(50 \%$, mainly bisaccate pollen grains), black opaque phytoclasts $(30 \%)$, and dinoflagellate cysts (over 15\%). The latter are dominated by Spiniferites spp. and the morphologically similar genus Achomosphaera. The following taxa occur frequently: Melitasphaeridium pseudorecurvatum, Operculodinium spp., M. choanophorum, Systematophora placacantha, and Lingulodinium machaerophorum; less common are: Nematosphaeropsis labyrinthus, Impagidinium sp., Reticulatosphaera actinocoronata, Pentadinium sp., and Hystrichokolpoma salacia.

Relatively frequent are specimens of reworked Paleogene taxa: Homotryblium tenuispinosum, Hystrichosphaeridium tubiferum, fragmentarily preserved (mainly isolated processes) Areosphaeridium (including $A$. diktyoplokum), and Cordosphaeridium.

A similar palynofacies dominated by bisaccate pollen grains and a relatively high ratio of dinoflagellate cysts (15\%) occurs in sample M-14 (Fig. 13). Also the taxonomical composition of the dinoflagellate cyst assemblage is similar to the one from the lower sample: it is dominated by Spiniferites and, to a lesser degree, by Systematophora placacantha. Achomosphaera spp., Melitasphaeridium pseudorecurvatum, Operculodinium spp., M. choanophorum, Reticulatosphaera actinocoronata, and Lingulodinium machaerophorum, which all occur frequently; Nematosphaeropsis labyrinthus, Labyrinthodinium truncatum, and Batiacasphaera? sp. are less numerous. Single specimens of Impagidinium and Cordosphaeridium cantharellum have been found. In this sample, as in sample $M-12$, reworked Paleogene taxa occur: Deflandrea sp., Areosphaeridium sp., and Hystrichosphaeridium tubiferum.
The palynofacies of sample M-15 - the highest of the samples studied - qualitatively resembles that of lower samples (Fig. 13), but significantly differs by much lower amounts of palynological organic matter. Also, the dinoflagellate cyst assemblage taxonomically generally resembles ones from samples $\mathrm{M}-14$ and $\mathrm{M}-12$, but specimens are much rarer. It is dominated by Spiniferites spp., and less frequently by Operculodinium spp. Rare or single specimens of the following taxa occur: Lingulodinium machaerophorum, Achomosphaera sp., Melitasphaeridium choanophorum, Labyrinthodinium truncatum, Impagidinium sp., Hystrichokolpoma salacia, Pentadinium sp., Nematosphaeropsis labyrinthus, and Batiacasphaera? sp.

\section{MINERALOGY}

The results of XRF analysis are shown in Table 2. In all samples studied calcite, quartz and smectite were recorded, and the latter mineral occurs in greater proportion in samples $\mathrm{M}-10$ and $\mathrm{M}-12$. The three minerals are accompanied, in the lower part of section studied (samples $\mathrm{M}-1$ and $\mathrm{M}-2$ ), by gypsum, feldspar, zeolite, pyrite, illite, and chlorite, and these minerals (except for gypsum) are present in other samples in the section. In the middle part of the section, aragonite and muscovite were identified (Table 2).

\section{INTERPRETATION}

\section{FORAMINIFERAL RECORD}

The dominant species recorded in the interval represented by samples M-1 to M-14 indicate a depth of ca. $50 \mathrm{~m}$ (Fig. 14) as 

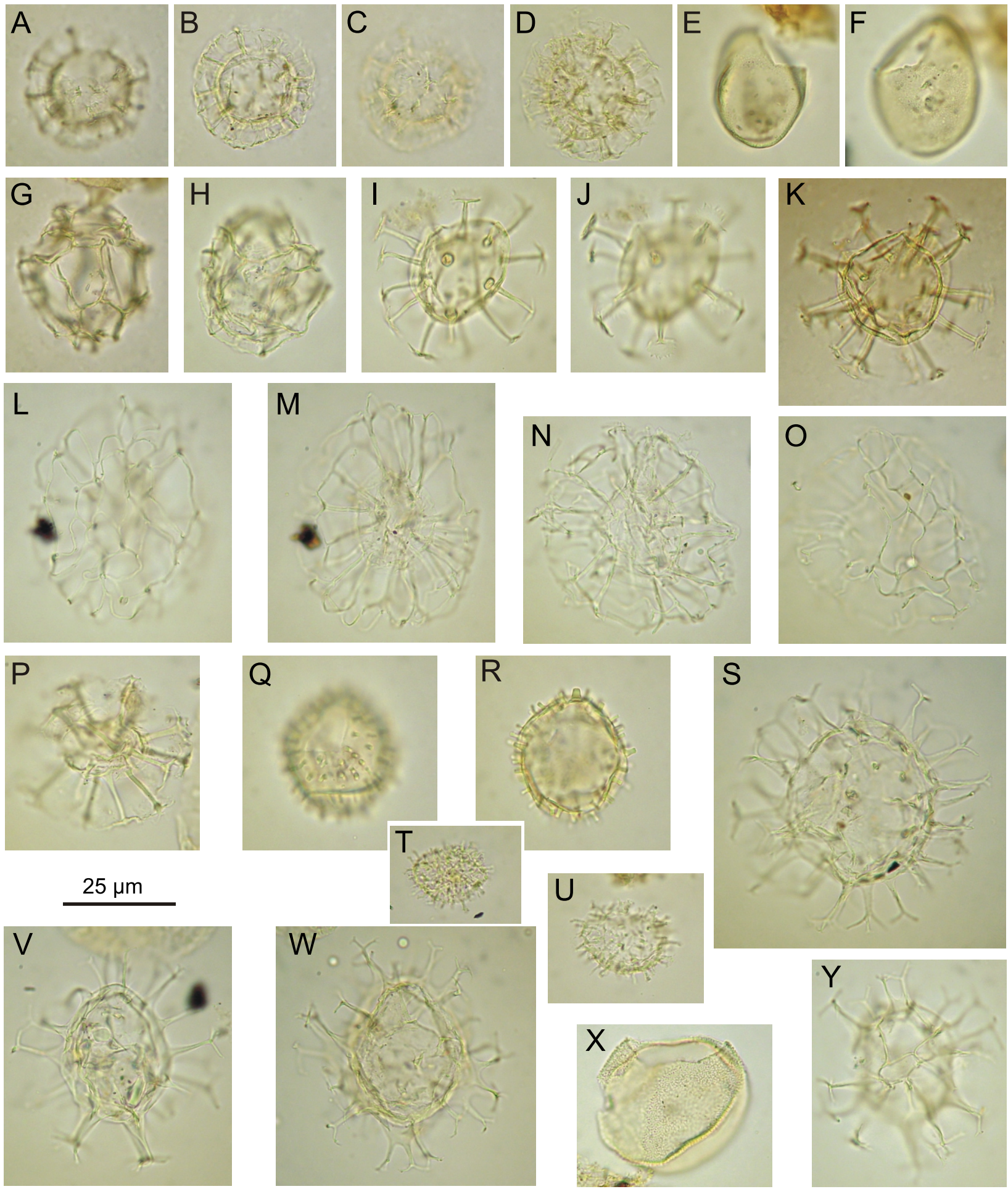

Fig. 11. Dinoflagellate cysts and acritarchs from Shchyrets

A-D - Labyrinthodinium truncatum (A-C: same specimen, various foci, M-15; D: M-14); E, F - Pyxidiniopsis sp. (both specimens M-14); G, H - Impagidinium spp. (G: M-15, H: M-14); I-K - Melitasphaeridium choanophorum (I, J: same specimen, various foci, M-14; K: M-15); L-O - Nematosphaeropsis labyrinthus (L, M and N, O: same specimens, various foci; both specimens: M-14); P Reticulatosphaera actinocoronata (M-14); Q, R - Operculodinium piaseckii (same specimen, various foci, M-14); $\mathbf{S}-$ Spiniferites sp. (M-14); T, U - Nannobarbophora gedlii (T: M-7, U: M-14); V - Achomosphaera sp. (M-14); W - Spiniferites sp. (M-14); X Batiacasphaera sp. (M-7); Y - Spiniferites ramosus (M-14) 

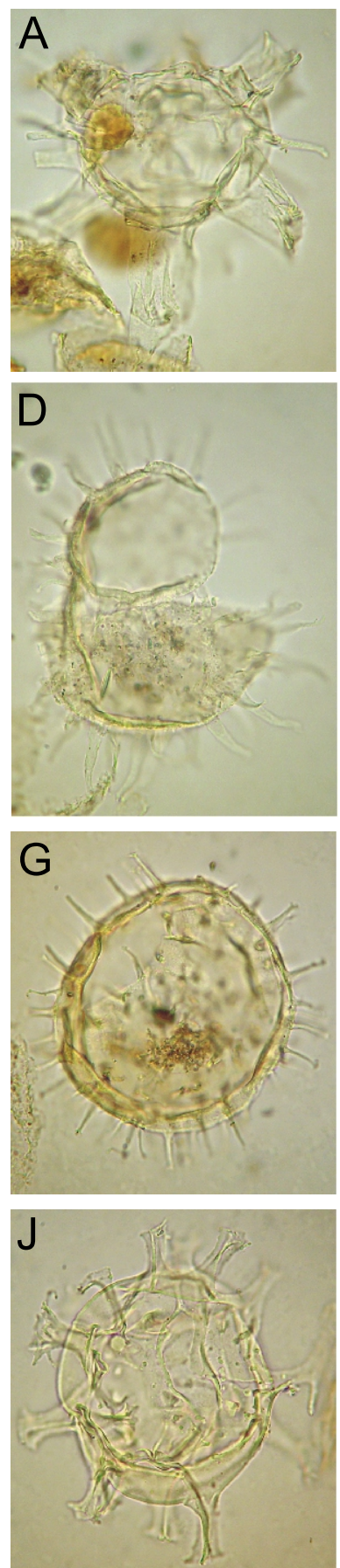

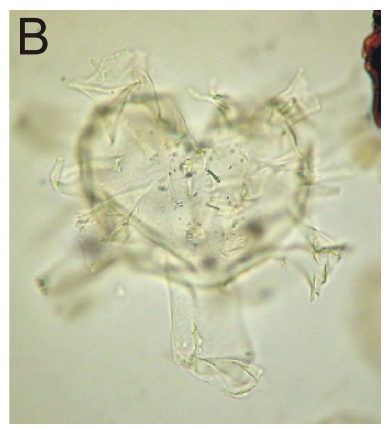

$25 \mu \mathrm{m}$
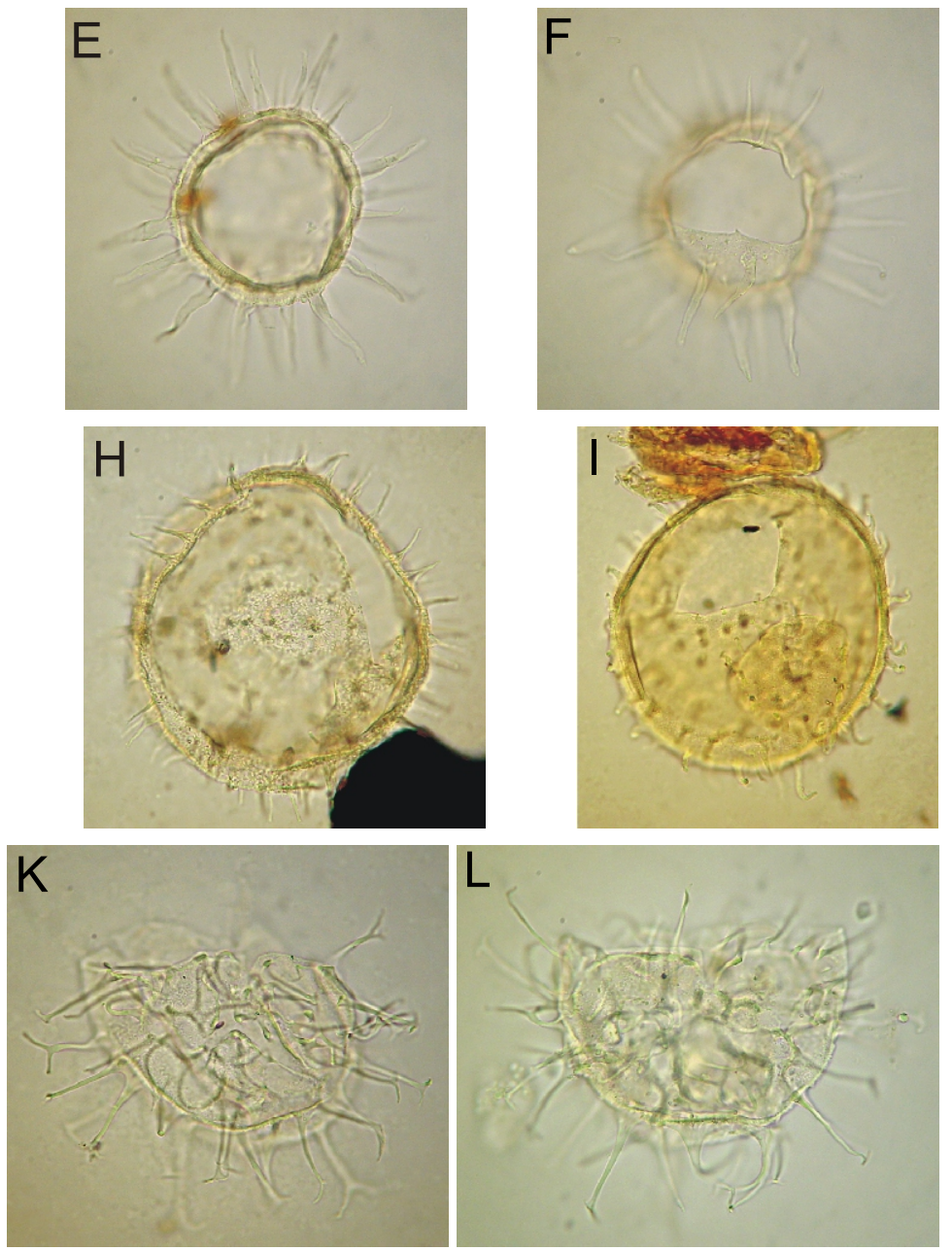

Fig. 12. Dinoflagellate cysts from Shchyrets

A, B - Hystrichokolpoma rigaudiae (both specimens: M-7); C - Pentadinium laticinctum (M-12); D-F Lingulodinium machaerophorum (D: M-14; E, F: same specimen, various foci, M-14); G - Operculodinium centrocarpum (M-15); H, I - Operculodinium spp. (both specimens: M-15); J - Spiniferites pseudofurcatus (M-15); K, L - Systematophora placacantha (K: M-15, L: M-14)

Bulimina elongata lives at depths of $>15 \mathrm{~m}$, Heterolepa dutemplei at depths of $>40 \mathrm{~m}$, and Globocassidulina at depths of $>50 \mathrm{~m}$ (Hohenegger, 2005). Very low P/B values (0-5\%) in the interval and taxonomic composition of planktonic foraminiferal assemblages also indicate inner shelf depths (Murray, 1991). Planktonic foraminifera, mostly Globigerina and rarely Globigerinoides, indicate a shallow cool sea. Globigerina bulloides is a mixed-layer, cold-water dweller adapted to more eutrophic waters, tolerant of a wide range of typical oceanic salinities (Pujol and Vergnaud-Grazzini, 1995; Majewski, 2003;
Majewski and Bohaty, 2010). Globigerinoides in turn is a surface-dweller common in warm, oligotrophic waters of the mixed layer, with highest abundances in regions where there is a permanent vertical stratification of the water column (Hemleben et al., 1989; Di Stefano et al., 2010).

Deepening of the sea is interpreted for interval starting from sample M-15 where Uvigerina dominates, which according to Hohenegger (2005) lives not shallower than $70 \mathrm{~m}$. At the same level the $\mathrm{P} / \mathrm{B}$ ratio significantly increases and exceeds $50 \%$ (Fig. 14). 


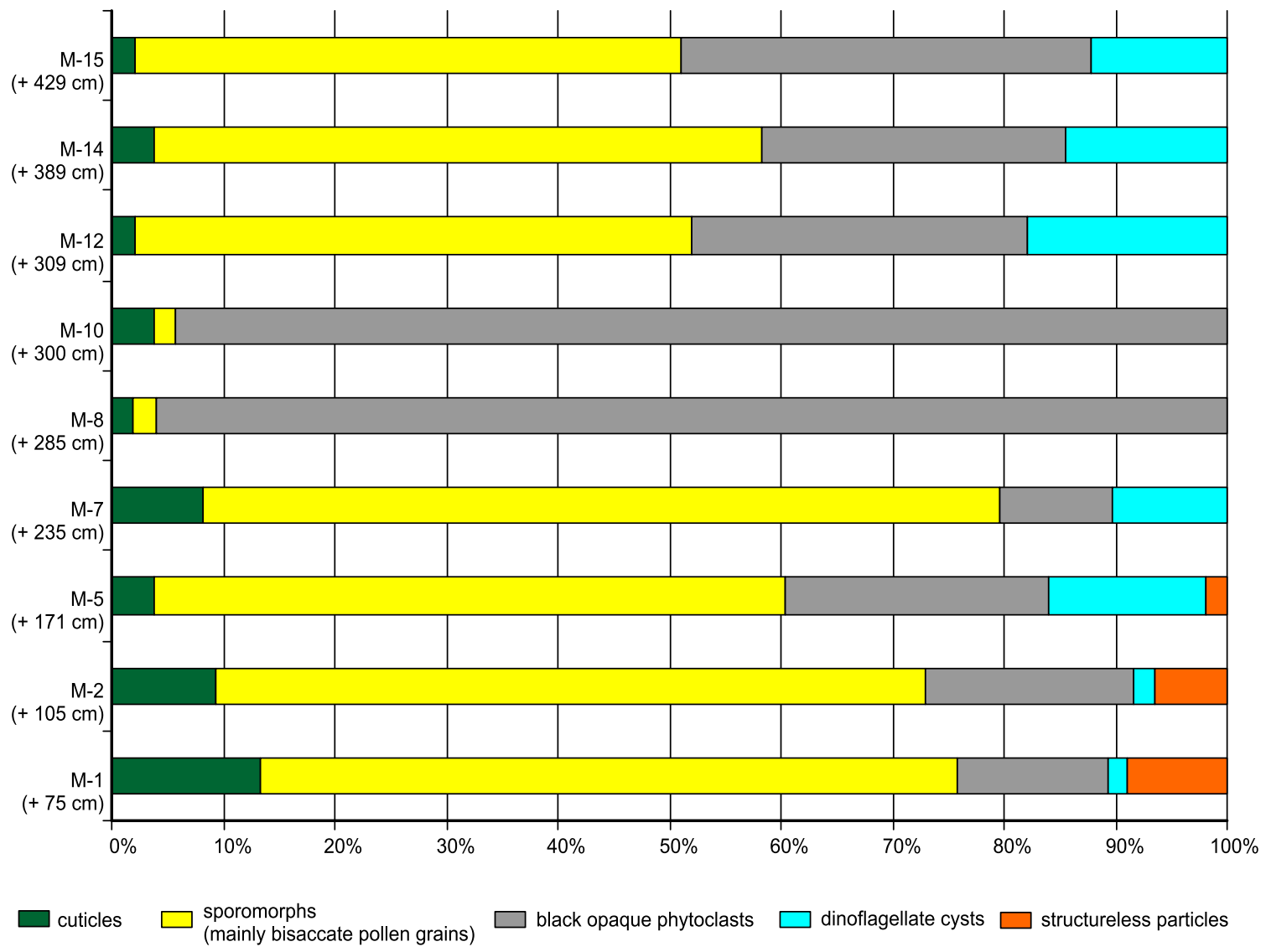

Fig. 13. Palynofacies changes in the Shchyrets succession

In the lowest part of the interval, the frequency of infaunal Bulimina is very high and exceeds $80 \%$. Very high dominance of Bulimina indicates probably not only very low oxygen levels at the sea floor causing stress for benthic life, but probably also increased salinity, as Bulimina is tolerant of both dysoxia and high bottom-water salinity (Verhallen, 1991). The amelioration of oxic conditions at the sea floor in the higher part of the section (sample M-2) is shown by a low-dominance assemblage, characterized by a relatively low abundance of dysoxic forms in favour of suboxic ones that are represented mostly by nodosariids, nonionids, and Lobatula lobatula; Cibicidoides spp. represent oxic forms.

Then, the deposition of thin tuffite bed at the sea bottom, possibly the result of Transcarpa-

Table 2 thian volcanic activity of Badenian age (see Table 2 Bilonizhka et al., 2012 with references therein), exterminated the biota for a short time (cf. Hess et al., 2001; Zágoršek et al., 2012). Hess et al. (2001), by monitoring the recolonisation of the Mt Pinatubo 1991 ash layer by benthic foraminifera, discovered that recolonisation was very fast and took only a few years for a complete recovery of the foraminiferal benthic communities. The steps of recolonisation were not recognized in the material studied. The M-8 sample overlying the tuffite bed contains a benthic foraminiferal assemblage reflecting a mesotrophic environment at surface waters and no oxygen deficit at the sea floor. The epifaunal dweller Heterolepa dutemplei constitutes there $>25 \%$ of the assemblage. This assemblage contains the highest oxic indices found in the entire section studied.

In the interval represented by samples M-7 to M-14 deep infaunally living foraminifera dominate: dysoxic, or opportunistic forms. Their contribution to the assemblages varies from 70 to 


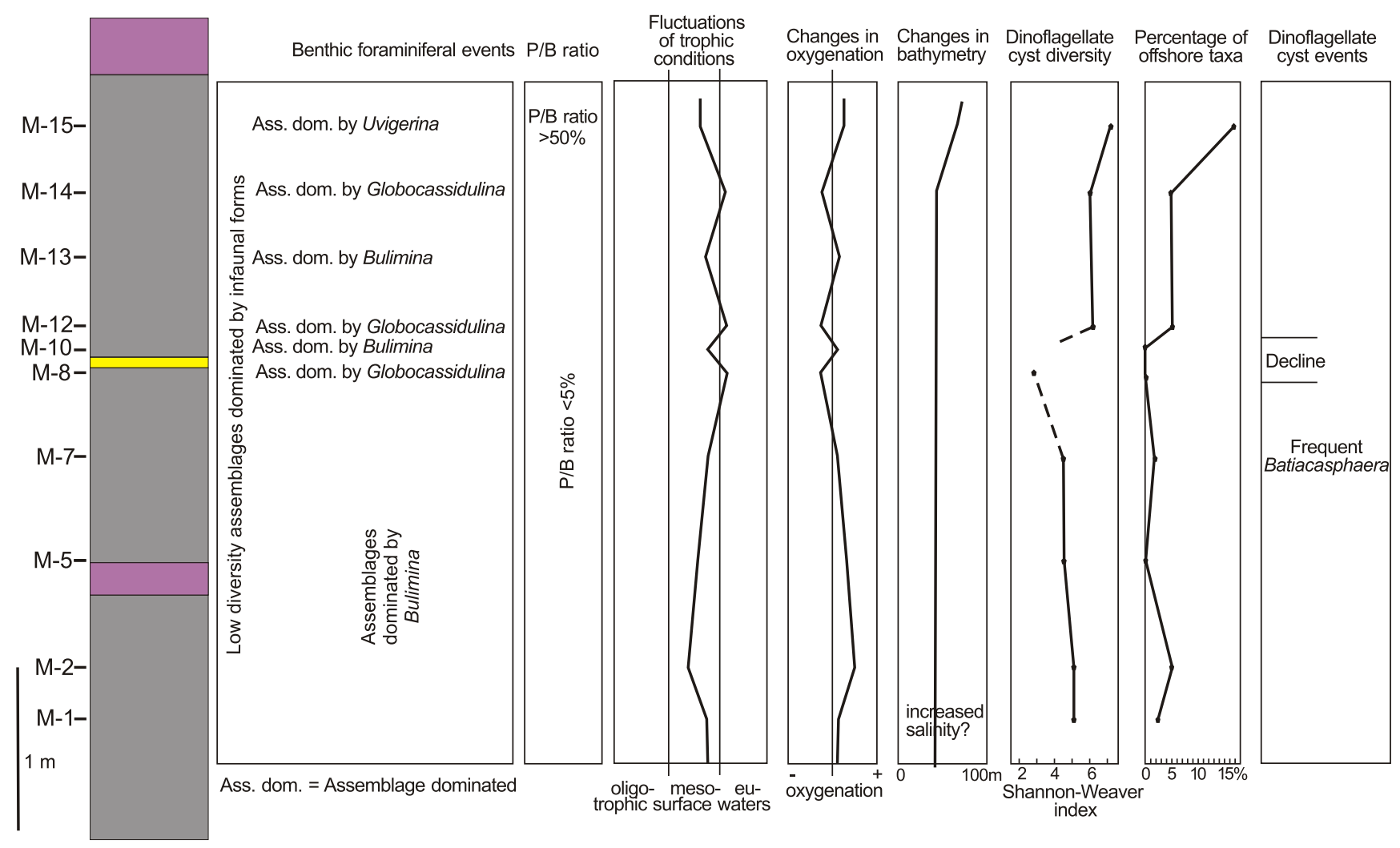

Fig. 14. Palaeoenvironmental changes in the Late Badenian basin at Shchyretsi based on interpretation of foraminifera and dinoflagellate cyst assemblages

$80 \%$, which indicates mesotrophic/eutrophic environments at surface waters, and a large influx of organic matter to the sea bottom, where a lot of oxygen was consumed for its degradation.

The benthic foraminiferal assemblages are composed mainly by Bulimina and Globocassidulina. However, their relative abundances vary from sample to sample. In samples M-7, M-10, and M-13 Bulimina dominates forming from 56 to $77 \%$ of the assemblages. The contribution of Globocassidulina in these samples varies from 15 to $25 \%$. On the other hand in samples $M-8$, $\mathrm{M}-12$, and M-14 Globocassidulina dominates in benthic foraminiferal assemblages and its contribution to the assemblages exceeds $60 \%$. Levels where small Globocassidulina dominate may indicate the highest deficit of oxygen at the sea floor. Small, thin-walled foraminiferal tests are common in low-oxygen environments where foraminifera must withstand the acidic conditions often associated with organic enrichment (Bernhard, 1986). Fursenkoina acuta, Astrononion perfossum, and Sigmoilinita tenuis are important contributors in these assemblages. Assemblages where Bulimina prevails are more diverse, which probably reflects better oxygenation at the sea floor (Fig. 14).

The reason for change in the relative abundances of Bulimina and Globocassidulina in this interval remains enigmatic. One of the possible reasons could be a change of type and/or quality of food sinking from the surface waters (cf. Peryt et al., 2002).

The benthic foraminiferal assemblage from the topmost sample (M-15) is also dominated by dysoxic forms, but there is a complete reorganization of the assemblage: Bulimina and Globocassidulina are absent, and Uvigerina forms $57 \%$ of the assemblage. Sphaeroidina bulloides, a shallow infauna dweller, is the second important component of this assemblage. Sigmoilinita tenuis and Pullenia bulloides reach $5 \%$ each of the total. A decreased contribution of dysoxic forms to the assem- blage to $62 \%$, dominance of Uvigerina (middle shelf - bathyal form), increased diversity and a high P/B ratio indicates deepening of the sea to middle shelf depth, a mesotrophic environment at the surface, a lower influx of organic matter to the bottom, and better oxygenation at the sea floor (Fig. 14).

In general, both benthic and planktonic $\delta^{13} \mathrm{C}$ values indicate the nutrient-rich conditions in the Ukrainian Carpathian Foredeep Basin during the Late Badenian, although they are probably the most clearly expressed in the lowest part of the section, possibly due to increased input of continental organic matter during the transgression. Negative $\delta^{13} \mathrm{C}$ values of Bulimina and Uvigerina indicating nutrient-rich and ${ }^{13} \mathrm{C}$-depleted pore-water conditions correspond to the dominance of low-oxygen benthic foraminiferal indicators, such as Bulimina elongata (cf. Kováčová and Hudáčková, 2009).

There are several factors controlling foraminiferal $\delta^{18} \mathrm{O}$ distribution, although temperature changes played a decisive role in the Carpathian Foredeep Basin as well as in the Vienna Basin (see discussion in Kováčová and Hudáčková, 2009). In turn, strongly negative $\delta^{18} \mathrm{O}$ values measured in Late Badenian planktonic foraminifers (see Figs. 8 and 9) were interpreted by Báldi (2006) as due to less saline surface water. In their study of Badenian foraminifera from the Vienna Basin, Kováčová et al. (2009) assumed a $\delta^{18} \mathrm{O}_{\text {water }}$ of $0 \%$, and calculated that palaeowater temperatures, if the equation of Epstein et al. (1953) is applied, would be $6.3-8.5^{\circ} \mathrm{C}$ for benthic foraminifers (mostly Uvigerina) and 9.7 to $17.7^{\circ} \mathrm{C}$ for Globigerina. Those values are similar to those recorded by us $\left(5.4-8.4^{\circ} \mathrm{C}\right.$ for Bulimina/Uvigerina if two anomalous values of 11.5 and $17.1^{\circ} \mathrm{C}$ are ignored, and $12.9-15.7^{\circ} \mathrm{C}$ for Globigerina). However, we assume that $\delta^{18} \mathrm{O}_{\text {water }}$ was higher, although most probably below $1 \%$. 
Palaeotemperatures calculated from the oxygen isotope ratios of foraminifers (Fig. 8) indicate differences between the bottom water and the water column (Fig. 8). The increase in $\Delta \delta^{18} \mathrm{O}$ (from $0.9 \%$ in sample 1 to $2.2 \%$ in sample $\mathrm{M}-15$ ) clearly suggests an upwards-increasing trend in the stratification of the water column. Such an increasing stratification trend was earlier recorded in other parts of the Central Paratethys: in the Vienna Basin (Kováčová et al., 2009), the Upper Silesia Basin (Gonera et al., 2000), and in the Pannonian Basin (Báldi, 2006), possibly due to modification of basin circulation (Kováčová et al., 2009).

\section{PALYNOLOGICAL RECORD}

A characteristic of the deposits studied is a palynofacies dominated by bisaccate pollen grains. This feature, associated with relatively common aquatic elements, and an almost complete lack of large cuticular remains, indicates a hemipelagic sedimentary setting devoid of direct, intense terrestrial influx. Dominating pollen grains were presumably transported by wind. Ratio changes of dinoflagellate cysts and pollen grains suggest slightly variable sedimentary conditions (Fig. 14).

Basal samples $\mathrm{M}-1$ and $\mathrm{M}-2$ contain a relatively low ratio of dinoflagellate cysts compared to the overwhelming pollen grains. This may reflect a proximal site influenced by an intense influx of pollen grains (either by wind or water currents). The higher samples $\mathrm{M}-5$ and $\mathrm{M}-7$ contain a higher ratio of dinoflagellate cysts, presumably resulting from a less intense land influx. This most likely reflects a more offshore sedimentary setting in comparison to the basal interval, although changes in hydrodynamic circulation or wind direction cannot be excluded. The latter may be responsible for the palynological content of following two samples $M-8$ and $M-10$, which contain very low amounts of palynological organic matter. Such content may be related to a very shallow lagoon environment, or an environment characterized by high-energetic hydrodynamic current activities (Fig. 14). A general shallowing at this level may be suggested by frequent occurrences of Batiacasphaera in the underlying sample M-7. This taxon commonly occurs in shallow-water Miocene deposits of the Carpathian Foredeep (see Gedl, 1996, 1997).

The highest part of the succession studied (samples M-12, $\mathrm{M}-14$ and $\mathrm{M}-15$ ) displays similar palynofacies to the one represented by samples M-5 and M-7. Hence, a similar sedimentary setting may be reconstructed: relatively frequent dinoflagellate cysts, associated with pollen grains (presumably wind-transported), point to hemipelagic sedimentation in a rather offshore setting. The latter feature of sedimentary setting is also supported by the occurrence of Nematosphaeropsis labyrinthus and Impagidinium sp. Although infrequent, these taxa are believed to be indicative of offshore waters (e.g., Morzadec-Kerfourn, 1977; Wall et al., 1977; Harland, 1983; Dale, 1996; Rochon et al., 1999; Vink et al., 2000), occur in almost all samples studied, and therefore may be symptomatic of the whole Shchyrets succession. Their percentage, however, reaches the highest values in the upper part of the section, above the barren samples $M-8$ and $M-10$, being the highest in the topmost sample $\mathrm{M}-15$. This may reflect a slight deepening of the basin, recorded in the uppermost part of the section studied. A similar interpretation may be based on dinoflagellate cyst assemblage diversity. This shows the lowest values in the basal part (samples M-1 to $M-7$ ), which may reflect a relatively shallow basin compared to the topmost part (samples M-12 to M-15).

\section{MINERALOGY}

There is no major variation of mineralogical composition in the section studied (Table 2). Clay mineral composition was strongly controlled by pyroclastic material alteration that resulted in the common occurrence of smectite (cf. Bilonizhka et al., 2012). As already mentioned, thin tufogenic intercalations abound at Shchyrets (Kudrin, 1966; Nejbert et al., 2012).

\section{DISCUSSION}

Both foraminiferal and dinoflagellate cyst assemblages indicate an open marine environment with normal-marine salinity (Fig. 14). Foraminifers are represented by both planktonic (mainly Globigerina and Globigerinoides) and benthic forms. Bulimina, Globocassidulina, Uvigerina, Sphaeroidina, Pullenia, Heterolepa, and Fursenkoina which are common to dominant in benthic foraminiferal assemblages are shelf-bathyal species (Murray, 1991, 2006; Hohenegger, 2005). A low diversity of benthic foraminiferal assemblages, with high dominance of infaunal dysoxic forms, indicates nutrient-rich surface waters and a deficit of oxygen at the sea floor. Fluctuations in relative abundances of dominant infaunal taxa indicate probably not only changes in the quantity of organic matter sinking from the surface but also in its type and/or quality. Dinoflagellate cyst assemblages from all samples studied are qualitatively similar (except those of samples M-8 and M-10, which contain no specimens or very infrequent ones). Being dominated by Spiniferites, they are taxonomically relatively diverse, pointing to a normal marine environment during deposition of the Shchyrets succession. The latter feature is confirmed by a virtual lack of species tolerant of hypersaline conditions (e.g., Polysphaeridium zoharyi; Wall and Dale, 1969; Dale, 1976; Wall et al., 1977; Morzadec-Kerfourn, 1979, 1983; Bradford and Wall, 1984; Edwards and Andrle, 1992), which have been recently described from approximately coeval deposits of Kudryntsi (Gedl and Peryt, 2011). The only indication of stress conditions in the material studied, presumably related to increased salinity, is the very high dominance of Bulimina and the occurrence of infrequent Leiosphaeridia in basal sample M-1 (Fig. 14). This seemingly prasinophycean alga (see GuyOhlson, 1996) is reported from various environments, but commonly from hypersaline ones (e.g., Brugman et al., 1994). In the Carpathian Foredeep this genus occurs in mid-Badenian evaporitic deposits (Gedl, 1997; Gedl in Peryt et al., 1997) or in strata directly overlying them (Gedl, 1999). This is in concert with the benthic and planktonic $\delta^{13} \mathrm{C}$ values clearly indicating nutrient-rich conditions, especially in the lowest part of the section, possibly due to an increased input of continental organic matter during the transgression.

The Kosiv suite at Yaziv Field, located $44 \mathrm{~km}$ NNW of Shchyrets in a roughly similar palaeogeographical location, consists of a $8.3 \mathrm{~m}$ thick section of the Verbovets beds followed by a $3 \mathrm{~m}$ thick section of the Prut and Kolomyia beds (Goretsky, 1977). Goretsky (1977) recorded the first planktonic fora- 
minifers (Globigerina bulloides) $5.1 \mathrm{~m}$ above the Ratyn Limestone, and a quite rich assemblage of benthic foraminifers (Cibicides, Bulimina, Neobulimina, Glandulina) occurs in the interval 5.8-8.3 $\mathrm{m}$ above the Ratyn Limestone. At Shchyrets, both benthic and planktonic foraminifers appear much lower in the stratigraphic section. This may be due to oxygenation and productivity changes in the marginal part of the Ukrainian Carpathian Foredeep Basin, close to its basinal part after the Badenian salinity crisis.

\section{CONCLUSIONS}

1. The marly shales overlying mid-Badenian gypsum and Ratyn Limestone at Shchyrets contain moderately- to well-preserved benthic (only calcareous) and planktonic foraminifers: thirty-eight species of benthic and nine species of planktonic foraminifers were recorded. The palynofacies is dominated by bisaccate pollen grains. Twenty-six taxa of dinoflagellate cysts were noted; infrequent reworked taxa from Upper Cretaceous and Paleogene were also recorded. Both foraminiferal and dinoflagellate cyst assemblages indicate an open marine environment with normal-marine salinity. It was rather a shallow marine basin with a limited influx of terrestrial organic matter, except for pollen grains, presumably transported by wind or water currents.

2. Changes in the relative abundances of dominant and common species within benthic foraminiferal assemblages, of dinoflagellate cysts, and of pollen grains indicate slightly variable sedimentary conditions.
3. Bulimina and Globocassidulina are the most common and dominant component of benthic foraminiferal assemblages, except of the uppermost part where they are lacking and Uvigerina dominates the assemblage. In the uppermost part the P/B ratio is $57 \%$ in contrast to the rest of the section, where it is $<5 \%$, and this indicates deepening of the sea. The latter is recorded in the palynological record by the highest percentage (over 16\%) of offshore taxa (Nematospaheropsis labyrinthus and Impagidinium) in the topmost sample, whereas it is $5 \%$ or lower in the remaining part of the section.

4. The composition of benthic foraminifer assemblages as well as both benthic and planktonic $\delta^{13} \mathrm{C}$ values indicate nutrient-rich waters, mesotrophic to eutrophic environments at the surface, and low oxygenated environments at the sea floor in the Ukrainian Carpathian Foredeep Basin during the Late Badenian. Negative $\delta^{13} \mathrm{C}$ values of Bulimina and Uvigerina indicating nutrient-rich and ${ }^{13} \mathrm{C}$-depleted pore-water conditions correspond to the dominance of low-oxygen benthic foraminiferal indicators, such as Bulimina elongata.

6. Palaeotemperatures calculated from the oxygen isotope ratios of foraminifers indicate differences between the bottom water and the water column and an upwards-increasing trend in the stratification of the water column.

Acknowledgements. The fieldwork and analyses were funded by research grant No. 6 P04D 00911 (Committee on Scientific Research) to T.M. Peryt and special grant No. Ukraina/193/2006 (Ministry of Science and Higher Education) to M. Kotarba. We thank A.V. Poberezhskyy for his help in the field. The comments and suggestions given by the journal reviewers, N. Hudàčková and A. Poberezhskyy, are appreciated.

\section{REFERENCES}

Andreyeva-Grigorovich, A.S., Kulchytsky, Y.O., Gruzman, A.D., Lozynyak, P.Y., Petrashkevich, M.I., Portnyagina, L.O., Ivanina, A.V., Smirnov, S.E., Trofimovich, N.A., Savitskaya, N.A., Shvareva, N.J., 1997. Regional stratigraphic scheme of Neogene formations of the Central Paratethys in the Ukraine. Geologica Carpathica, 48: 123-136.

Báldi, K., 2006. Paleoceanography and climate of the Badenian (Middle Miocene, 16.4-13.0 Ma) in the Central Paratethys based on foraminifera and stable isotope $\left(\delta^{18} \mathrm{O}\right.$ and $\left.\delta^{13} \mathrm{C}\right)$ evidence. International Journal of Earth Sciences, 95: 119-142.

Bernhard, J.M., 1986. Characteristic assemblages and morphologies of benthic foraminifera from anoxic, organic-rich deposits: Jurassic through Holocene. Journal of Foraminiferal Research, 16: 207-215

Bernhard, J.M., Sen Gupta, B., 1999. Foraminifera of oxygen-depleted environments. In: Modern Foraminifera (ed. B. Sen Gupta): 200-216. Kluwer Academic Publishers, Dordrecht.

Bilonizhka, P., laremchuk, I., Hryniv, S., Vovnyuk, S., 2012. Clay minerals of Miocene evaporites of the Carpathian Region, Ukraine. Biuletyn Państwowego Instytutu Geologicznego, 449: 137-146.

Bobrinskaya, O.G., Gruzman, A.D., Kresheninnikov, V.A., Serova, M.Y., Venglinskyi, I.V., 1998. Stratigraphy of the Oligocene and Miocene deposits of the western Ukraine and Moldavia. Abhandlungen der Senckenbergischen Naturforschenden Gesellschaft, 549: 34-43.

Bradford, M.R., Wall, D.A., 1984. The distribution of Recent organic-walled dinoflagellate cysts in the Persian Gulf, Gulf of Oman, and northwestern Arabian Sea. Palaeontographica, Abt. B, 192: 16-84.
Brugman, W.A., Van Bergen, P.F., Kerp, J.H.F., 1994. A quantitative approach to Triassic palynology: the Lettenkeuper of the Germanic Basin as an example. In: Sedimentation of Organic Particles (ed. A. Traverse): 409-429. Cambridge.

Cicha, I., Rögl, F., Rupp, C., Čtyroka, J., 1998. Oligocene-Miocene foraminifers of the Central Paratethys. Abhandlungen der Senckenbergischen Naturforschenden Gesellschaft, $\mathbf{5 4 9}$.

Corliss, B.H., Chen, C., 1988. Morphotype patterns of Norwegian Sea deep-sea benthic foraminifera and ecological implications. Geology, 16: 716-719.

Dale, B., 1976. Cyst formation, sedimentation and preservation: factors affecting dinoflagellate assemblages in Recent sediments from Trondheimsfjord, Norway. Review of Palaeobotany and Palynology, 22: 39-60.

Dale, B., 1996. Dinoflagellate cyst ecology: modelling and geological applications. In: Palynology: Principles and Applications (eds. J. Jansonius and D.C. McGregor), 3: 1249-1275. American Association of Stratigraphic Palynologists Foundation, Dallas, Texas.

de Leeuw, A., Filipescu, S., Mațenco, L., Krijgsman, W., Kuiper, K., Stoica, M., 2013. Paleomagnetic and chronostratigraphic constraints on the Middle to Late Miocene evolution of the Transylvanian Basin (Romania): implications for Central Paratethys stratigraphy and emplacement of the Tisza-Dacia plate. Global and Planetary Change, 103: 82-98.

Di Stefano, A., Verducci, M., Lirer, F., Ferraro, L., laccarino, S.M., Hüsing, S.K., Hilgen, F.J., 2010. Paleoenvironmental conditions preceding the Messinian Salinity Crisis in the Central Mediterranean: integrated data from the Upper Miocene Trave sec- 
tion (Italy). Palaeogeography, Palaeoclimatology, Palaeoecology, 297: 37-53.

Epstein, S., Buchsbaum, R., Lowenstam, H.A., Urey, H.C., 1953. Revised carbonate-water temperature scale. GSA Bulletin, 64: 1315-1326.

Edwards, L.E., Andrle, V.A.S., 1992. Distribution of selected dinoflagellate cysts in modern marine sediments. In: Neogene and Quaternary Dinoflagellate Cysts and Acritarchs (eds. M.J. Head and J.H. Wrenn): 259-288. American Association of Stratigraphic Palynologists Foundation.

Emiliani, C., 1955. Pleistocene temperatures. Journal of Geology, 63: $538-578$.

Garecka, M., Olszewska, B., 2011. Correlation of the Middle Miocene deposits in SE Poland and western Ukraine based on foraminifera and calcareous nannoplankton. Annales Societatis Geologorum Poloniae, 81: 309-330.

Gedl, P., 1996. Middle Miocene dinoflagellate cysts from the Korytnica clays (Góry Świętokrzyskie Mountains, Poland). Annales Societatis Geologorum Poloniae, 66: 191-218.

Gedl, P., 1997. Palynofacies of the Miocene deposits in the Gliwice area (Upper Silesia, Poland). Bulletin of the Polish Academy of Sciences, Earth Sciences, 45: 191-201.

Gedl, P., 1999. Palaeoenvironmental and sedimentological interpretations of the palynofacies analysis of the Miocene deposits from the Jamnica S-119 borehole (Carpathian Foredeep, Poland). Geological Quarterly, 43 (4): 479-492.

Gedl, P., 2005. In situ and recycled dinoflagellate cysts from Middle Miocene deposits at Bęczyn, Carpathian Foredeep, Poland. Studia Geologica Polonica, 124: 371-394.

Gedl, P., Peryt, D., 2011. Dinoflagellate cyst, palynofacies and foraminiferal records of environmental changes related to the Late Badenian (Middle Miocene) transgression at Kudryntsi (western Ukraine). Annales Societatis Geologorum Poloniae, 81: 331-349.

Gerasimov, L.S., Makarova, I.V., Chalyi, S.V., Plotnikov, A.A., Gerasimova, I.I., Polkunova, G.V., Evtushko, T.L., 2005. Derzhavna geologichna karta Ukrainy 1:200 000. Karpatska seriya. Arkushi M-34-XXIII (Przemyśl), M-34-XXIV (Drohobych). Poyasnyuvalna zapiska (in Ukrainian). DKPRUkrainy, Kyiv.

Gonera, M., Peryt, T.M., Durakiewicz, T., 2000. Biostratigraphical and palaeoenvironmental implications of isotopic studies $\left({ }^{18} \mathrm{O}\right.$ ${ }^{13} \mathrm{C}$ ) of middle Miocene (Badenian) foraminifers in the Central Paratethys. Terra Nova, 12: 231-238.

Goretsky, V.A., 1977. On the stratigraphy of the Miocene terrigene rocks in the External Zone of the Precarpathians Foredeep (in Russian with English summary). Paleontologicheskiy Sbornik, 14: 79-82.

Górka, M., Studencka, B., Jasionowski, M., Hara, U., Wysocka, A., Poberezhskyy, A., 2012. The Medobory Hills (Ukraine). Middle Miocene reef systems in the Paratethys: their biological diversity and litofacies. Biuletyn Państwowego Instytutu Geologicznego, 449: 147-174.

Guy-Ohlson, D., 1996. Prasinophycean algae. In: Palynology: principles and applications (eds. J. Jansonius and D.C. McGregor), 1: 181-189. American Association of Stratigraphic Palynologists Foundation; Dallas, Texas.

Harland, R., 1983. Distribution maps of recent dinoflagellate cysts in bottom sediments from the North Atlantic Ocean and adjacent seas. Palaeontology, 26: 321-387.

Hemleben, C., Spindler, M., Anderson, O.R., 1989. Modern Planktonic Foraminifera. Springer, New York.

Hess, S., Kuhnt, W., Hill, S., Kaminski, M.A., Holbourn, A.E.L., de Leon, M., 2001. Monitoring the recolonization of the Mt. Pinatubo 1991 ash layer by benthic foraminifera. Marine Micropaleontology, 43: 119-142.

Hohenegger, J., 2005. Estimation of environmental paleogradient values based on presence/absence data: a case study using benthic foraminifera for paleodepth estimation. Palaeogeography, Palaeoclimatology, Palaeoecology, 217: 115-130.
Hohenegger, J., Ćorić, S., Wagreich, M., 2014. Timing of the Middle Miocene Badenian Stage of the Central Paratethys. Geologica Carpathica, 65: 55-66.

Jones, R.W., Charnock, M.A., 1985. "Morphogroups" of agglutinating foraminifera. Their life positions and feeding habits and potential applicability in (paleo)ecological studies. Revue de Paléobiologie, 4: 311-320.

Jorissen, F.J., Barmawidjaja, D.M., Puskaric, S., van der Zwaan, G.J., 1992. Vertical distribution of benthic foraminifera in the northern Adriatic Sea: the relation with organic flux. Marine Micropaleontology, 19: 131-146.

Kaiho, K., 1994. Benthic foraminiferal dissolved-oxygen index and dissolved oxygen levels in the modern ocean. Geology, 22: 719-722.

Kaminski, M.A., 2012. Calibration of the Benthic Foraminiferal Oxygen Index in the Marmara Sea. Geological Quarterly, 56 (4): 757-764.

Kotarba, M.J., Peryt, T.M., Koltun, Y.V., 2011. Microbial gas system and prospectives of hydrocarbon exploration in Miocene strata of the Polish and Ukrainian Carpathian Foredeep. Annales Societatis Geologorum Poloniae, 81: 523-548.

Kouwenhoven, T.J., van der Zwaan, G.J., 2006. A reconstruction of late Miocene Mediterranean circulation patterns using benthic foraminifera. Palaeogeography, Palaeoclimatology, Palaeoecology, 238: 373-385.

Kováč, M., Andreyeva-Grigorovich, A., Bajraktarević, Z., Brzobohatý, R., Filipescu, S., Fodor, L., Harzhauser, M., Nagymarosy, A., Oszczypko, N., Pavelić, D., Rögl, F., Saftić, B., Sliva, L'., Studencka, B., 2007. Badenian evolution of the Central Paratethys Sea: paleogeography, climate and eustatic sea-level changes. Geologica Carpathica, 58: 579-606.

Kováčová, P., Hudáčková, N., 2009. Late Badenian foraminifers from the Vienna Basin (Central Paratethys): stable isotope study and paleoecological implications. Geologica Carpathica, 60: 59-70.

Kováčová, P., Emmanuel, L., Hudáčková, N., Renard, M., 2009. Central Paratethys paleoenvironment during the Badenian (Middle Miocene): evidence from foraminifera and stable isotope $\left(\delta^{13} \mathrm{C}\right.$ and $\left.\delta^{18} \mathrm{O}\right)$ study in the Vienna Basin (Slovakia). International Journal of Earth Sciences, 98: 1109-1127.

Kudrin, L.N., 1966. Stratigraphy, facies and ecological analysis of fauna of the Paleogene and Neogene deposits of the Forecarpathians (in Russian). Lvov, Izd. Lvovsk. Univ.

Kurovets, I., Prytulka, G., Shpot, Y., Peryt, T.M., 2004. Middle Miocene Dashava Formation sandstones, Carpathian Foredeep, Ukraine. Journal of Petroleum Geology, 27: 373-388.

Loeblich, A.R. Jr., Tappan, H., 1987. Foraminiferal Genera and their Classification. Van Nostrand Reinhold, New York.

Loubére, P., 1996. The surface ocean productivity and bottom water oxygen signals in deep water benthic foraminiferal assemblages. Marine Micropaleontology, 28: 247-261.

Loubére, P., 1997. Benthic foraminiferal assemblage formation, organic carbon flux and oxygen concentrations on the outer continental shelf and slope. Journal of Foraminiferal Research, 27: 93-100.

Łomnicki, A.M., 1897. Geological Atlas of Galicia (in Polish). Text to fasc. 10, part 1. Kraków.

Majewski, W., 2003. Water-depth distribution of Miocene planktonic foraminifera from ODP Site 744, Southern Indian Ocean. Journal of Foraminiferal Research, 33: 144-154.

Majewski, W., Bohaty, S.M., 2010. Surface-water cooling and salinity decrese during the Middle Miocene climate transition at Southern Ocean ODP Site 747 (Kerguelen Plateau). Marine Micropaleontology, 74: 1-14.

Morzadec-Kerfourn, M.T., 1977. Les kystes de dinoflagellés dans les sédiments récents le long des côtes Bretonnes. Revue de Micropaléontologie, 20: 157-166.

Morzadec-Kerfourn, M.T., 1979. Indicateurs écologiques du domaine littoral: végétation et plancton organique. Océanis, $\mathbf{5}$ : 207-213. 
Morzadec-Kerfourn, M.T., 1983. Interêt de dinoflagellés pour l'établissement de reconstruction paléogéographique: exemple du Golfe de Gabes (Tunésie). Cahiers de Micropaléontologie, 4 $15-22$.

Murray, J.W., 1991. Ecology and Palaeoecology of Benthic Foraminifera. Longman, Avon.

Murray, J.W., 2006. Ecology and Applications of Benthic Foraminifera. Cambridge University Press, Cambridge.

Nejbert, K., Śliwiński, M.G., Benowitz, J., Layer, P., Yatsyshyn, A., Tomeniuk, O., Olszewska-Nejbert, D., Babel, M., 2012 ${ }^{40} \mathrm{Ar}{ }^{39} \mathrm{Ar}$ dating of late Badenian pyroclastic deposits from Schyrets' (near Lviv, Ukraine) and its stratigraphic significance. In: Environmental, Structural and Stratigraphical Evolution of the Western Carpathians (eds. Š. Józsa, D. Reháková and R. Vojtko). 8th Conference 2012, Abstract Book, 6th-7th December, Bratislava, 33.

Odrzywolska-Bieńkowa, E., Olszewska, B., 1996. Rząd Foraminiferida Eichwald. In: Budowa geologiczna Polski (eds. L. Malinowska and M. Piwocki) (in Polish), 3. Atlas skamieniałości przewodnich i charakterystycznych, część 3a: 530-614.

Oszczypko, N., Oszczypko-Clowes, M., 2012. Stages of development in the Polish Carpathian Foredeep basin. Central European Journal of Geosciences, 4: 138-162.

Oszczypko, N., Krzywiec, P., Popadyuk, I., Peryt, T., 2006. Carpathian Foredeep Basin (Poland and Ukraine): its sedimentary, structural, and geodynamic evolution. AAPG Memoir, 84: 293-350.

Peryt, D., 2013. Foraminiferal record of marine transgression during deposition of the Middle Miocene Badenian evaporites in Central Paratethys (Borków section, Polish Carpathian Foredeep). Terra Nova, 25: 298-306.

Peryt, D., Gedl, P., 2010. Palaeoenvironmental changes preceding the Middle Miocene Badenian salinity crisis in the northern Polish Carpathian Foredeep Basin (Borków quarry) inferred from foraminifers and dinoflagellate cysts. Geological Quarterly, 54 (4): 487-508

Peryt, D., Alegret, L., Molina, E., 2002. The Cretaceous/Paleogene $(K / P)$ boundary at Ain Settara (Tunisia): restructuring of benthic foraminiferal assemblages. Terra Nova, 14: 101-107.

Peryt, T.M., 1996. Sedimentology of Badenian (middle Miocene) gypsum in eastern Galicia, Podolia and Bukovina (West Ukraine). Sedimentology, 43: 571-588.

Peryt, T.M., 2006. The beginning, development and termination of the Middle Miocene Badenian salinity crisis in Central Paratethys. Sedimentary Geology, 188-189: 379-396.

Peryt, T.M., Peryt, D., 1994. Badenian (Middle Miocene) Ratyn Limestone in western Ukraine and northern Moldavia: microfacies, calcareous nannoplankton and isotope geochemistry. Bulletin of the Polish Academy of Sciences, Earth Sciences, 42: 127-136.

Peryt, T.M., Karoli, S., Peryt, D., Petrichenko, O.I., Gedl, P., Durkovičova, J., Dobieszyńska, Z., 1997. Westernmost occurrence of the Middle Miocene Badenian gypsum in Central Paratethys (Kobeřice, Moravia, Czech Republic). Slovak Geological Magazine, 3: 105-120.

Peryt, T.M., Hryniv, S.P., Anczkiewicz, R., 2010. Strontium isotope composition of Badenian (Middle Miocene) Ca-sulphate deposits in West Ukraine: a preliminary study. Geological Quarterly, $\mathbf{5 4}$ (4): 465-476.

Peryt, T.M., Durakiewicz, T., Peryt, D., Poberezhskyy, A., 2012 Carbon and oxygen isotopic composition of the Middle Miocene Badenian gypsum-associated limestones of West Ukraine. Geologica Acta, 10: 319-332.

Petryczenko, O.I., Panow, G.M., Peryt, T.M., Srebrodolski, B.I., Pobereżski, A.W., Kowalewicz, W.M., 1994. Zarys geologi mioceńskich formacji ewaporatowych ukraińskiej czesści zapadliska przedkarpackiego (in Polish). Przegląd Geologiczny, 42: 734-737.
Pishvanova, L.S., 1969. Stratigraphical and facial distribution of Foraminifera in Miocene deposits of the western part of Ukrainian SSR. Rocznik Polskiego Towarzystwa Geologicznego, 39: 335-349.

Pujol, C., Vergnaud-Grazzini, C., 1995. Distribution patterns of live planktic foraminifers as related to regional hydrography and productive systems of the Mediterranean Sea. Marine Micropaleontology, 25: 187-217.

Rochon, A., De Vernal, A., Turon, J.-L., Matthiessen, J., Head, M.J., 1999. Distribution of recent dinoflagellate cysts in surface sediments from the North Atlantic and adjacent seas in relation to sea-surface parameters. American Association of Stratigraphic Palynologists, Contribution Series, 35: 1-146.

Rögl, F., 1998. Palaeogeographic considerations for Mediterranean and Paratethys seaways (Oligocene to Miocene). Annalen des Naturhistorischen Museums in Wien, 99: 279-310.

Studencka, B., Prysyazhnyuk, V.A., Ljul'eva, S.A., 2012. First record of the bivalve species Parvamussium fenestratum (Forbes, 1844) from the Middle Miocene of the Paratethys. Geological Quarterly, 56 (3): 513-528.

Śliwiński, M., Babel, M., Nejbert, K., Olszewska-Nejbert, D., Gąsiewicz, A., Schreiber, B.C., Benowitz, L.A., Layer, P., 2012. Badenian-Sarmatian chronostratigraphy in the Polish Carpathian Foredeep. Palaeogeography, Palaeoclimatology, Palaeoecology, 326-328: 12-29.

Thomas, E., 1980. Details of Uvigerina development in the Cretan Mio-Pliocene. Utrecht Micropaleontological Bulletins, 23: 1-167.

Van der Zwaan, G.J., 1982. Paleoecology of late Miocene Mediterranean Foraminifera. Utrecht Micropaleontological Bullettins, 25: 1-202.

Van der Zwaan, G.J., 1983. Quantitative analysis and the reconstruction of benthic foraminiferal communities. Reconstruction of marine paleoenvironments. Utrecht Micropaleontological Bulletins, 30: 49-69.

Van der Zwaan, G.J., Duijnstee, I.A.P., den Dulk, M., Ernst, S.R., Jannink, N.T., Kouwenhoven, T.J., 1999. Benthic foraminifers: proxies or problems? A review of paleocological concepts. Earth- Science Reviews, 46: 213-236.

Van Hinsbergen, D.J.J., Kouwenhoven, T.J., van der Zwaan, G.J., 2005. Paleobathymetry in the backstripping procedure: correction for oxygenation effects on depth estimates. Palaeogeography, Palaeoclimatology, Palaeoecology, 221: 245-265.

Vashchenko, V.O., Turchynova, S.M., Turchynov, I.I., Polikha, G.G., 2007. Derzhavna geologichna karta Ukrainy 1:200 000 Karpatska seriya. Arkush M-35-XXV (Ivano-Frankivsk) Poyasnyuvalna zapiska (in Ukrainian). UkrDGI, Kyiv.

Verhallen, P., 1991. Late Pliocene to early Pleistocene Mediterranean mud-dwelling foraminifera; influence of a changing environment on community structure and evolution. Utrecht Micropaleontological Bulletins, 40: 1-219.

Vink, A., Zonneveld, K.A.F., Willems, H., 2000. Organic-walled dinoflagellate cysts in western equatorial Atlantic surface sediments: distribution and their relation to environment. Review of Palaeobotany and Palynology, 112: 247-286.

Wall, D., Dale, B., 1969. The "hystrichosphaerid" resting spore of the dinoflagellate Pyrodinium bahamense Plate, 1906. Journal of Phycology, 5: 140-149.

Wall, D., Dale, B., Lohmann, G.P., Smith, W.K., 1977. The environmental and climatic distribution of dinoflagellate cysts in modern marine sediments from regions in the north and south Atlantic Oceans and adjacent seas. Marine Micropaleontology, 2: 121-200.

Zágoršek, K., Nehyba, S., Tomanová Petrová, P., Hladilová, Š., Bitner, M.A., Doláková, N., Hrabovský, J., Jašková, V., 2012. Local catastrophe caused by tephra input near Premyslovice (Moravia, Czech Republic) during the Middle Miocene. Geological Quarterly, 56 (2): 269-284. 